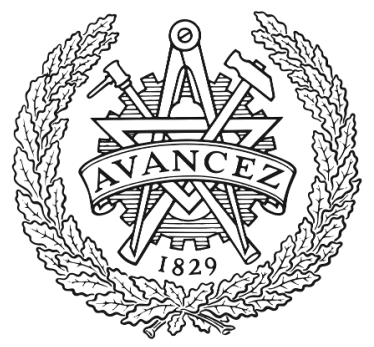

CHALMERS

UNIVERSITY OF TECHNOLOGY

\title{
Tradable performance standards in the transportation sector
}

Downloaded from: https://research.chalmers.se, 2023-04-26 09:48 UTC

Citation for the original published paper (version of record):

Yeh, S., Burtraw, D., Sterner, T. et al (2021). Tradable performance standards in the transportation sector. Energy Economics, 102. http://dx.doi.org/10.1016/j.eneco.2021.105490

N.B. When citing this work, cite the original published paper. 


\title{
Tradable performance standards in the transportation sector
}

\author{
Sonia Yeh ${ }^{\text {a, }}$, Dallas Burtraw ${ }^{\mathrm{b}}$, Thomas Sterner $^{\mathrm{c}}$, David Greene ${ }^{\mathrm{d}}$ \\ ${ }^{\text {a }}$ Chalmers University of Technology, Gothenburg, Sweden \\ ${ }^{\mathrm{b}}$ Resources for the Future, Washington, DC, USA \\ ${ }^{\mathrm{c}}$ Department of Economics, Gothenburg University, Gothenburg, Sweden \\ ${ }^{\mathrm{d}}$ University of Tennessee, Knoxville, TN, USA
}

\section{A R T I C L E I N F O}

\section{Keywords:}

Policy instruments

Transportation

Performance-based standard

Innovation

Mitigation cost

Complementary policy

\begin{abstract}
A B S T R A C T
Performance standards have a long history in environmental policy. A performance standard sets a standard of technology performance but leaves technology choice to producers; it increases the relative costs of technologies with undesirable performance characteristics and lowers the costs of technologies with desirable characteristics. The primary motivations are to promote innovation, to address consumers' undervaluation of efficiency, and to reduce externalities, such as air pollution and the risks of dependence on foreign oil. In the past decade, trading has been incorporated (thus termed as tradable performance standard, TPS) into several U.S. transportation programs: regulations for greenhouse gas emissions from passenger cars and trucks (national), zero-emission vehicle programs (10 states), the Renewable Fuel Standard (national), and low-carbon fuel standards (two states). TPS allows for equalization of marginal costs across eligible technologies and is therefore more efficient than pure regulations. We show that sectoral TPS programs have high credit prices but low price effects on products and provide strong incentives for upstream innovation and technology transformation. Unlike emissions pricing, however, they do not have a strong output effect: consumers do not bear the full cost of the pollution and do not have incentive to reduce consumption of polluting products. Given that the expected carbon price may be too low to substantially affect transportation demand or technology change, combining TPS with a carbon price may be necessary to drive innovation and achieve a sustained low-carbon transformation in the sector.
\end{abstract}

\section{Introduction}

Performance standards have a long history in the US transportation sector, beginning at the national level with the Corporate Average Fuel Economy (CAFE) standards enacted by Congress in 1975 (Greene, 1990), and in California with the Zero Emission Vehicle (ZEV) program adopted by the California Air Resources Board (CARB) in 1990 (Collantes and Sperling, 2008). Unlike technology mandates, which prescribe specific technology (e.g., a three-way catalytic converter), performance standards set a goal (e.g., maximum emissions per unit of performance, or vehicle efficiency of at least $\mathrm{x}$ miles per gallon), enabling the regulated entity to choose any technology mix that achieves that outcome (Bergek and Berggren, 2014). Performance standards can force technology innovation by specifying a standard that cannot be met with conventional technology (Lee et al., 2010) or that imposes higher cost (Gerard and Lave, 2005). When implemented as technology volume requirements (e.g., requiring that products with a specific technology constitute $\mathrm{x}$ percentage of all new sales), performance standards push an identified technology into the market, usually with the intent of achieving cost reductions through market penetration. When implemented as an emissions intensity standard, performance standards provide flexibility by enabling compliance through incremental improvements without specifying technology choice. Tradability or averaging of performance across facilities introduces additional flexibility and thus improves the cost-effectiveness of the policy.

TPS programs have been prominent in the US electricity sector, exemplified in 29 states' renewable portfolio standards and in the Obama administration's proposed Clean Power Plan. Recently, China announced its intent to implement the largest rate-based emissions trading program in the world in its electricity sector (Goulder and Morgenstern, 2018). Some incentive-based regulatory programs address the transportation sector. In the bonus-malus (Latin for good-bad, here meaning credit-tax) system in France, consumers receive a rebate for low-emission vehicles but pay a fee for higher-emission vehicles. The European Union's Renewable Energy Directive mandates that clean sources account for minimum shares of the energy consumed in road and

\footnotetext{
* Corresponding author.

E-mail address: sonia.yeh@chalmers.se (S. Yeh).
} 
rail transport in member countries.

Few programs in the transportation sector, however, allow companies to trade credits for compliance. ${ }^{1}$ The most prominent examples have been in the United States. The US lead phasedown in the 1980s employed a tradable performance standard that rapidly drove the lead content of gasoline to negligible levels (Kerr and Newell, 2003). Current examples include the national regulations for greenhouse gas (GHG) emissions from passenger cars and trucks (introduced in 2009, with first trading in 2012), zero-emission vehicle programs in 10 states (first adoption in 1990, first trading in 2012), the national Renewable Fuel Standard (introduced in 2005, first trading in 2010), and California's Low Carbon Fuel Standards (adopted in 2010, first trading in 2011).

Earlier attention to performance standards focused on their ability to promote innovation (Nentjes et al., 2007; Bergek and Berggren, 2014; Klier and Linn, 2016) and to address imperfect competition, consumers' undervaluation of energy efficiency (Greene, 2019; Fischer, 2010), consumers' inelasticity to fuel price changes (Hughes et al., 2008; Lin and Prince, 2013), and externalities such as air pollution and the risks of dependence on foreign sources of oil (Lin and Prince, 2009; Schnepf and Yacobucci, 2013). In the absence of federal leadership in implementing ambitious carbon pricing, attention has shifted to the cost-effectiveness of TPS compared with carbon pricing (Nentjes and Woerdman, 2012). It is often argued that without comprehensive, global carbon pricing, TPS programs must increasingly be part of emissions reduction policies if we are to control the total carbon concentration in the atmosphere (Sperling and Nichols, 2012).

Broadly speaking, pollution can be abated either through changes in technology (inputs and production technologies) or through reduced consumption of the goods that embed emissions. Abatement of emissions through changes in technology is the main objective of TPS programs. In contrast, a price on carbon emissions provides incentives to change both technology (input substitution and abatement effects) and consumption levels or technology (the output effect) (Goulder et al., 1999). Emissions pricing puts an equal value on emissions reductions throughout the value chain; this generally means that it is the most efficient policy (Sterner, 2007).

TPS programs are more common than carbon pricing in the US transportation sector, for several reasons. The sector has some of the highest GHG mitigation costs of developed countries' economies (Intergovernmental Panel on Climate Change (IPCC), 2014; Creutzig et al., 2015; Yeh et al., 2017; Gillingham and Stock, 2018), and therefore either very high fuel taxes or separate policy instruments other than carbon pricing are needed to achieve GHG reduction goals. Even with high fuel taxes in Europe, for example, emissions reduction targets still face significant challenges. Fuel tax increases have provoked strong backlashes, such as the "yellow vests" movement in France. In contrast, both politically and economically, the production subsidy to desired technologies implicit in the TPS approach (explained below) drives technological change while reducing the visible costs to consumers, compared with achieving the same outcome with carbon pricing. Nonmarket-based policy instruments such as regulations, technology mandates, and standards focus directly on technology change, but they may result in substantial differences in marginal abatement costs even within the same industry. Tradable standards are more economically efficient because they allow for equalization of marginal costs across technologies and firms. But unlike emissions pricing, they do not have a strong output effect: consumers do not bear the full cost of the pollution

\footnotetext{
1 Sweden, for example, has a program for increasing biofuel content of diesel and gasoline called Reduktionsplikten (reduction mandate). Each year the fuel producers must achieve a certain percentage of biofuel. These obligations are in some cases tradable, making this almost a TPS, although there has little discussion of this aspect. Similarly, the European mandatory $\mathrm{CO}_{2}$ emission targets for new passenger cars allow vehicle manufacturers to pool their sales to avoid penalties.
}

and do not have incentive to reduce consumption of polluting products.

Our paper begins by evaluating TPS programs, focusing on realworld implementation of two national programs and two state-level programs as they have been implemented in California (Section 2). We then compare carbon pricing to a TPS in the form of an intensity standard in terms of their price effects, return to investment in innovation (Section 3), and mitigation costs at the program and system levels (Section 4). We look specifically at the policies' effectiveness in reducing GHG emissions but do not address other important aspects, such as equity effects, that are reviewed elsewhere. In Section 5 we summarize the lessons learned and offer recommendations.

\section{Review of notable programs}

A performance standard can target performance (e.g., sales of electric vehicles, vehicle efficiency in miles per gallon) or emissions intensity (e.g., carbon intensity of fuels, emissions intensity of vehicles). The requirements typically become more stringent over time, often leading to higher credit prices and incentives to innovate. Compliance requirements can be placed upstream (on producers or suppliers) or downstream (on consumers). Often, the point of regulation is placed as far upstream as possible to reduce the regulatory burden for administration, reporting, and monitoring. Small producers below a specified threshold are frequently exempted.

TPS compliance options typically include (1) producing products that meet or exceed the standard, thereby generating credits that can be sold to other producers; (2) purchasing surplus credits from other producers; and (3) using banked credits or credits borrowed against future credits (if allowed). Monitoring, verification, and enforcement requirements are similar to those in other environmental markets, with the noncompliance penalty becoming the de facto ceiling for the credit price. If there is a cap on credit prices that is lower than the marginal compliance cost, then the standard will not be met (Greenstone and Nath, 2019). One of the prime stated purposes is to foment technical progress. If this is achieved, then the rise in credit prices may be dampened or even reversed.

In the four following sections we go through in turn a number of prominent programs, two for vehicles and two for fuels. Two in California and two are federal US programs. Section 2.5 summarizes.

\subsection{Regulations for passenger vehicle GHG emissions}

The US Corporate Average Fuel Economy (CAFE) regulations for light-duty vehicles were enacted by Congress in 1975 and implemented by the National Highway Traffic Safety Administration (NHTSA) in 1978. The 1975 law established separate sales-weighted average miles per gallon standards for passenger cars and light trucks and required each manufacturer's new-vehicle fleets to meet the relevant standard. ${ }^{2}$ The standards for cars have required somewhat greater relative increases than those for trucks (US Environmental Protection Agency (EPA), 2020). Within their own regulated fleets, manufacturers could bank credits and borrow against future credits, but credit trading between manufacturers was not allowed. In 2007, Congress amended the law to allow credit trading. It also required that a manufacturer's standard be indexed to the size of the vehicles it produced, as measured by their "footprints."3 That year, the US Supreme Court ruled that GHGs were a pollutant as defined under the US Clean Air Act, a decision that affirmed the authority of the Environmental Protection Agency (EPA) to regulate motor vehicle GHG emissions. NHTSA, EPA, and the California Air Resources Board (CARB) jointly implemented coordinated fuel

\footnotetext{
${ }^{2}$ The standard defines average as the harmonic mean of miles per gallon, which is equivalent to the mean of gallons per mile.

3 A vehicle's footprint is defined as the average of its front and rear axle track width multiplied by its wheelbase.
} 
economy and GHG emissions standards for model years 2012 through $2025 .^{4}$

When fuel economy or GHG standards are binding, they impose shadow prices on inefficient, higher-emitting vehicles in proportion to their deviation from the standard but subsidize fuel-efficient, low-GHG vehicles (Davis and Knittel, 2019). In the case of the footprint standard, the shadow pricing is relative to the target for a vehicle of a given type and size (Liu and Greene, 2014). Before trading between firms was allowed, shadow prices exhibited substantial heterogeneity across manufacturers because of differences in their market segments and their access to fuel-efficient technology (Jacobsen, 2013; Anderson and Sallee, 2011). This heterogeneity should incentivize trading between firms. One analysis estimated that full trading across vehicle classes and between manufacturers could reduce the compliance costs of a $40 \%$ increase in fuel economy from 2012 to 2020 by more than $10 \%$ (Rubin et al., 2009). A small reduction in the benefits of trading, however, might result from oligopoly and oligopsony in credit markets. Another reason the full potential of trading might not be realized is that manufacturers may choose to pay fines if the cost of meeting the standards exceeds the fine.

Before footprint standards and credit trading, manufacturers of luxury imported vehicles, including Mercedes-Benz, BMW, Porsche, Volvo, Daimler Chrysler, and Jaguar Land Rover, accumulated more than $\$ 870$ million in fines (nominal value) between 1983 and 2012 (Fig. 1). Some companies-Fiat Chrysler, Jaguar Land Rover, and Volvo - continued to pay fines after 2012, when trading became available, but the number of companies paying fines fell significantly. The fines translate to less than $\$ 100$ per vehicle except for luxury brands, such as Jaguar Land Rover ( $\$ 200$ per vehicle) and Ferrari Maserati, Saleen, and Spyker (over $\$ 600$ per vehicle).

During 2008-2015, the initial years of CAFE and GHG credit trading, nearly all firms were accumulating credits, and trades were very infrequent (Fig. 2), suggesting that the standards were likely nonbinding or that firms were expecting compliance costs to rise (Bialek and Shrader, 2019). Of the credits earned from 2012 to 2018, three firms (Honda, Tesla, and Toyota) accounted for $69 \%$. The same three firms supplied 94\% of the credits sold in 2018 (Fig. 2).

Because buyers and sellers arrange sales bilaterally, the program lacks transparency: the quantity of trades and prices, as well as possible side agreements, are not reported. Bialek and Shrader (2019) used banking behavior in CAFE to identify expectations of marginal abatement costs. Leard and McConnell (2017), using Tesla's 2020 Form 10-k filings with the Securities and Exchange Commission (SEC) for the sales of GHG credits, as well as the settlement between EPA and Hyundai and Kia for violating the standard, estimated credit prices at $\$ 36-\$ 63 / \mathrm{Mg}$ (Table 1). Our own estimates using Tesla's filing data yielded lower estimates of $\$ 10-\$ 18 / \mathrm{Mg}$ for 2017 and 2018 (see the following section).

\subsection{Zero-emission vehicle (ZEV) programs}

The California Air Resources Board first adopted the ZEV requirement in 1990. Currently there are nine states that have adopted California's ZEV regulations: Connecticut, Maine, Maryland, Massachusetts, New York, New Jersey, Oregon, Rhode Island and Vermont. Auto manufacturers are required to produce a number of ZEVs and plug-in hybrids each year, sufficient to yield credits that correspond to a specified percentage of their total California sales. The percentage was $4.5 \%$ in 2018 and rises to $22 \%$ by 2025 . Each vehicle receives one to four credits, based on its electric driving range. The more electric range a vehicle has, the more credits it receives. Auto manufacturers can also purchase credits to achieve compliance and bank credits for future use. Manufacturers must comply at the end of each compliance period and

\footnotetext{
4 The Trump administration revoked California's authority to regulated GHG emissions in 2019. The validity of the revocation is currently being litigated.
}

can carry excess credits over to the next period.

The numerous ZEV credit categories and calculations reflect the several kinds of low-emission vehicles available: full battery-electric vehicles (BEVs), hydrogen fuel-cell vehicles, plug-in hybrid-electric transitional vehicles (TZEVs), partial ZEVs (PZEVs), and advanced technology (AT) PZEVs. Prior to 2015, the credit unit was called nonmethane organic gas (NMOG) mass emission (grams per mile), which was simplified to ZEV credits after 2015. Fig. 3(a) shows ZEV credit trades for 2012-2018. Tesla has generated the most credits by far for sale to the other car companies (68\%); Toyota is second (10\%). ${ }^{5}$ Toyota also bought the most credits (32\%), followed by Fiat/Chrysler (16\%), Honda (13\%), and Ford (11\%).

Like other transportation sector TPS programs, the market for the ZEV program is closed (i.e., trading is allowed only among regulated parties), and credits are transferred directly between two companies or through other arrangements, without going through a public marketplace. Credit transactions must be reported, but not credit prices. In 2016 Tesla sold ZEV credits to Toyota and in 2017 to Toyota, Fiat Chrysler, and Subaru, and in 2017 and 2018 Fiat Chrysler sold ZEV credits to Honda. Companies also bank a significant amount of credits for future use or sales. On August 31, 2018, for example, Toyota held about as many ZEV credits in the bank as the total credits sold by Tesla in all previous years (Fig. 3(b)).

ZEV credit sales have provided crucial financial support for Tesla, especially in the early years of the program. In general, Tesla vehicles earn about four ZEV credits per BEV sold, depending on the model (Forbes, 2017). Credit sales constituted $135 \%{ }^{6}$ of Tesla's gross profit (or about $\$ 17,000$ per vehicle across all models) in 2012; the value decreased to $15 \%$ (or about $\$ 2550$ per vehicle across all models) in 2019 (Fig. 4(b)). Overall, Tesla sold more than $\$ 1.05$ billion in ZEV credits in 2009-2019, according to its SEC filings. Each ZEV credit could theoretically be worth up to $\$ 5000$ (the fine for noncompliance), although the market value is typically far less. Tesla's ZEV credit sales are estimated at around \$1000-\$4200 per ZEV credit except for 2013, when the value is estimated to have been close to $\$ 7000$ per ZEV credit. In 2013 , Tesla realized approximately $\$ 28,000$ in ZEV credit value on each sale of Model S (priced at $\$ 70,000$ to $\$ 100,000$ per vehicle). In addition to ZEV credit sales, Tesla also benefited from GHG credit sales (see Section 2.1), reported at \$315 million in 2018 (Fig. 4(a)).

\subsection{US renewable fuel standard (RFS)}

The national RFS program requires that a certain volume of renewable fuels replace or reduce petroleum-based transportation fuel, heating oil, or jet fuel. The RFS was created in 2005 and expanded under the Energy Independence and Security Act of 2007, which increased the volume of renewable fuels to be blended into transportation fuel to 36 billion gallons by 2022 . The four renewable fuel categories under the RFS are biomass-based diesel, cellulosic biofuel, advanced biofuel (biodiesel or sugarcane ethanol), and total renewable fuel (nonadvanced or conventional biofuel, such as corn ethanol). The maximum levels of lifecycle GHG emissions compared with baseline fuels (gasoline or diesel) are shown in Fig. 5, where the height of the dots (right side) illustrates the maximum allowable lifecycle carbon intensity of each fuel type.

\footnotetext{
${ }^{5}$ Note that before 2015, Toyota sold only AT PZEV (clean hybrids), essentially discounted ZEV, credits.

6 This implies that Tesla lost money selling cars, and that its entire gross profits came from selling ZEV credits. Gross profit = Revenue - Cost of Revenue, not including operating expenses (including R\&D, general administrative, etc.). Revenue includes automotive sales, automotive leasing, services and other, energy generation and storage segment. Cost of Revenue includes all costs associated with generating Revenue. Revenue on the sale of regulatory credits is part of the automotive revenue (sales plus leasing).
} 


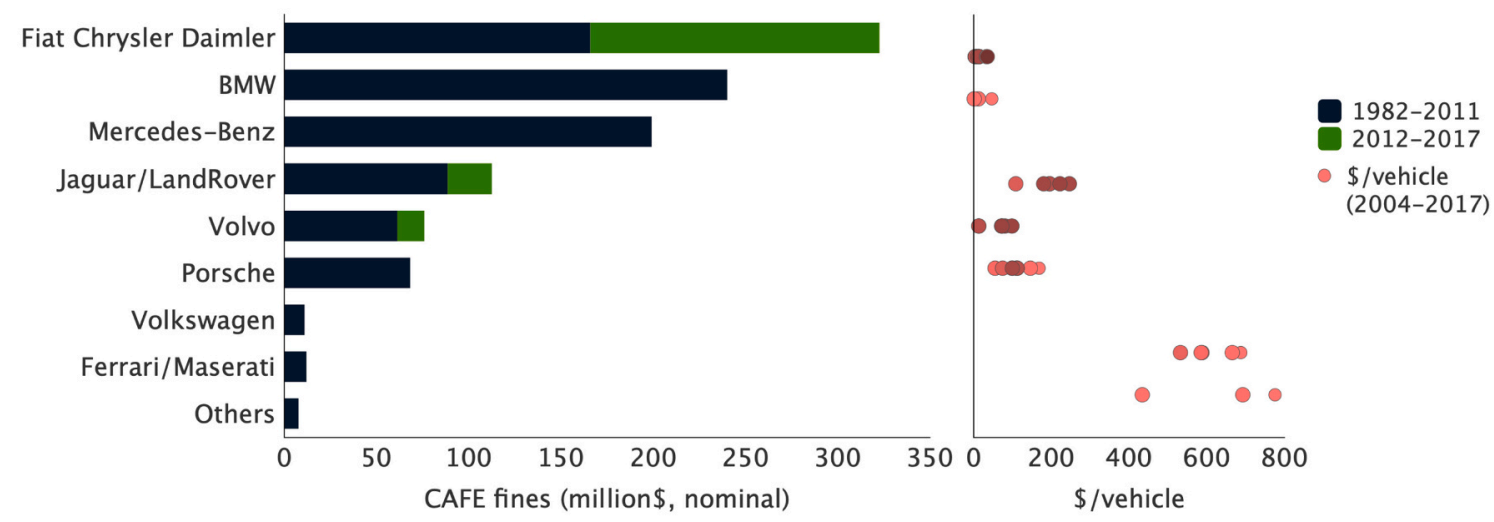

Fig. 1. Summary of CAFE fines, by manufacturer, 1982-2017.

Sales production volume data are available only for 2004-2018 (US Environmental Protection Agency (EPA), 2020). GHG credit trading started in 2012. Also shown are the estimated annual fines in dollars per vehicle by company (2004-2017, from lighter shades in the earlier years to darker shades in the later years). Smaller companies are omitted. Source: National Highway Traffic Safety Administration (NHTSA) (2020).

(a)

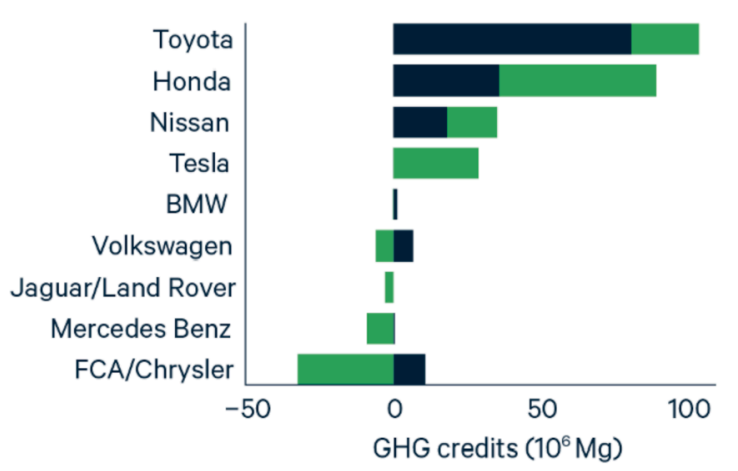

(b)

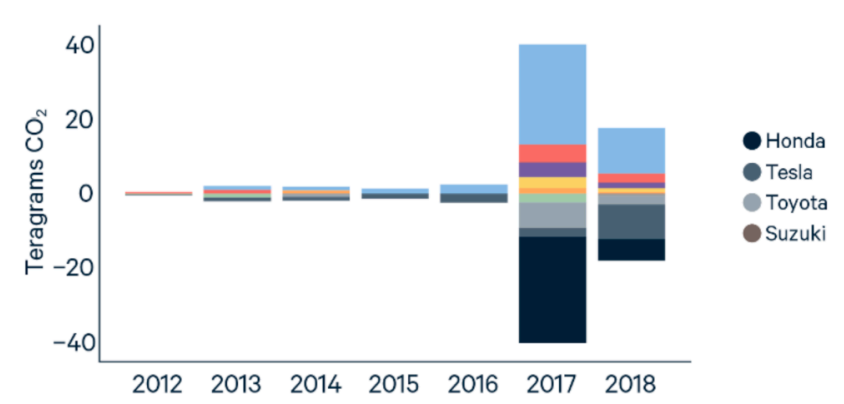

Table 1

GHG credit prices (\$/Mg), 2012-2018.

\begin{tabular}{llllllll}
\hline Source & 2012 & 2013 & 2014 & 2015 & 2016 & 2017 & 2018 \\
\hline $\begin{array}{c}\text { Leard and McConnell } \\
\text { (2017) }\end{array}$ & $\$ 36$ & $\$ 63$ & $\$ 42$ & - & - & - & - \\
Authors' estimates* & $\$ 36$ & $\$ 62$ & $\$ 63$ & $\$ 42$ & - & $\$ 10$ & $\$ 18$ \\
\hline
\end{tabular}

" Authors' estimates are based on US Environmental Protection Agency (EPA) (2020) and Tesla's annual financial reports.

Obligated parties under the RFS program are refiners or importers of gasoline or diesel fuel. Compliance is achieved by blending renewable fuels into transportation fuel, or by obtaining credits to meet an EPAspecified renewable volume obligation. EPA calculates and establishes these obligations every year through rulemaking, based on the RFS volume requirements and projections of gasoline and diesel production
Fig. 2. GHG credits, deficits, purchases, and sales, by manufacturer, 2009-2018.

(a) Total EPA GHG credits (+) and deficits (-) by company, 2009-2018. For example, Fiat Chrysler (FCA) accumulated deficits and also purchased credits for compliance whereas Toyota accumulated net credits and sold some credits. Smaller companies are omitted. Source: US Environmental Protection Agency (EPA) (2020). (b) Light-duty vehicle GHG emission credit sales $(<0)$ and purchases $(>0)$ by manufacturer by model year. Manufacturers not shown sold or purchased few or no credits during the 2012-2018 period.

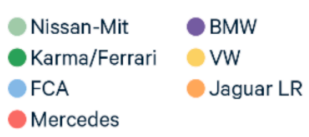

Mercedes for the coming year. The standards are converted into percentages, and obligated parties must demonstrate compliance annually. Credits are called renewable identification numbers (RINs). Each fuel type is assigned a D-code, which identifies the renewable fuel type based on the feedstock used, fuel type produced, energy inputs, and GHG reduction thresholds, among other requirements. The RFS program's four renewable fuel standards are nested within each other. That is, a fuel with a higher GHG percentage reduction can be used to meet the standards for a lower GHG percentage reduction, but not vice versa. For example, RINs for advanced biofuel (biodiesel or sugarcane ethanol) can be used to meet the total renewable fuel standards (corn ethanol). This has important implications for the price of RINs, discussed below.

RFS has created incentives for production of corn ethanol (D6) and biodiesel or renewable diesel (D4) (Fig. 5(a)). The D6 RIN price increased dramatically, from a few cents in 2012 to more than $\$ 1$ in 2013, when in 2013 the gasoline fuel mix hit a "blend wall"-the 
(a)

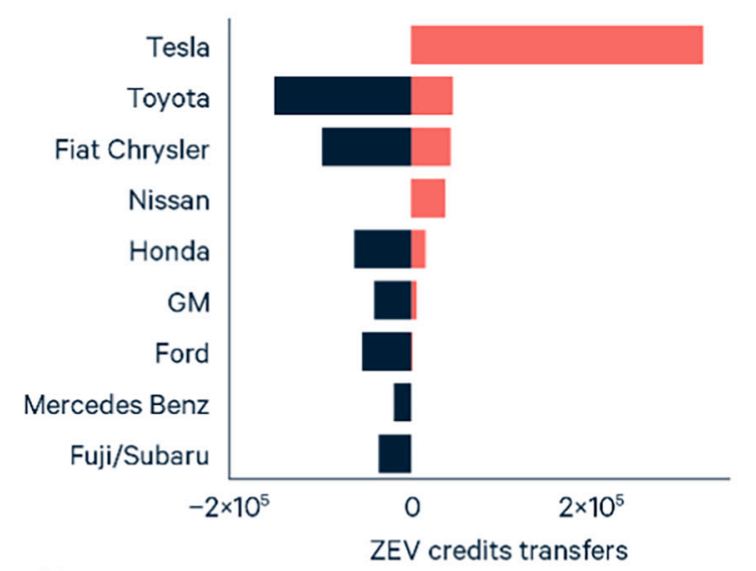

(b)

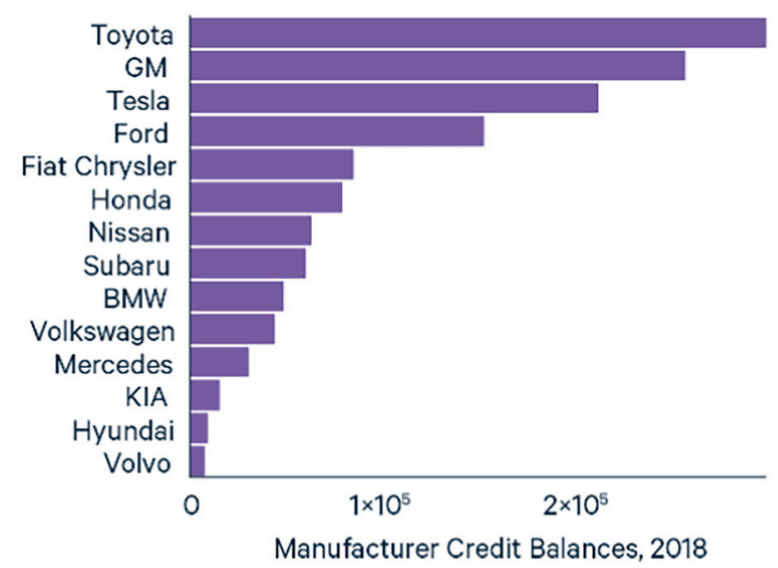

Fig. 3. California ZEV credits, deficits, and credit balances, by manufacturer. (a) Total ZEV credits bought (-) and sold (+) by manufacturer, 2012-2018. Credits from 2012 to 2014 were divided by 0.035 to convert grams/mile nonmethane organic (NMOG) gas credits to ZEV credits. (b) ZEV credit balances as of August 31, 2018. Smaller companies are omitted. Source: California Air Resources Board (CARB). (2020b).

maximum amount of ethanol $(10 \%$, or E10) that can be blended into regular gasoline without any risk or fear of causing engine damage in conventional vehicles. After the saturation of the E10 pool when the blend wall was hit, any additional volume of ethanol can only be blended as E85 (85\% ethanol). Because the use of E85 is limited to flexible-fuel (dual-fuel) vehicles with specialized engines and the sales volume of E85 is small, it was difficult to sell or blend more ethanol to generate D6 RINS, causing the D6 RIN price to rise in 2013 (Burkholder, 2015). After 2013, RIN prices of corn ethanol (D6), biomass diesel (D4), and advanced biofuel (D5) started to converge because the nesting nature of RFS allows flexible compliance across fuel types, effectively lowering the RIN prices. Because cellulosic biofuel never materialized at scale, its RIN prices were significantly higher, but they dropped after 2018, when renewable natural gas (biogas) was included as a compliance option to be counted as cellulosic biofuel.

\subsection{Low-carbon fuel standards (LCFS)}

California's LCFS, adopted in 2010, is the first major public initiative to codify lifecycle concepts into law (Sperling and Yeh, 2009; Yeh et al., 2016). The same policy was adopted by Oregon in 2016 as the Clean Fuels Program. The carbon intensity (CI) of fuels is measured on a lifecycle basis-that is, emissions from extraction or cultivation of feedstock, production, transportation, and use of the fuel are included. The legislation calls for at least a 10\% reduction in lifecycle GHG emissions per unit of energy $\left(\mathrm{gCO}_{2} \mathrm{e} / \mathrm{MJ}\right)$ ) by 2020 and $20 \%$ by 2030 . Oil refiners can sell low-carbon fuels or buy credits generated by low-carbon fuel producers, such as biofuels producers or electric utilities that sell power to electric vehicles.

The alternative fuels for compliance are largely biofuels from corn ethanol, biodiesel, and renewable diesel (Fig. 6(a)) because these fuels have the lowest compliance costs and are compatible with existing vehicle technologies. In contrast with the RFS, however, LCFS allows other fuel types, including electricity, and has created strong incentives for fuel producers to lower the CI values. As ethanol hit the blend wall in 2013 (Section 2.3), ethanol's volume stayed flat (Fig. 6(a)) but continued generating more LCFS credits (Fig. 6(b)) because of higher production efficiency (e.g., more output per biomass, new technologies like corn oil extraction), the use of lower-carbon energy sources as inputs in the production processes, and a switch to biomass feedstock with lower carbon emissions, such as crop residues, used cooking oil, and wastes from food processing. As a result, the $\mathrm{CI}$ of ethanol and biodiesel across their lifecycle has decreased by 33 and 41\%, respectively (Fig. 6 (b), right vertical axis). Also shown are the volume-weighted average lifecycle CI of fuels and total alternative fuels in California (Fig. 6(b), right vertical axis). The $\mathrm{CI}$ values of ethanol and biodiesel have drastically decreased over time (shown as arrows) while the CI of other fuels has remained mostly unchanged (shown as dots with their 2019Q4 values).

The price fluctuations earlier in the program were due in large part to policy uncertainty, including legal challenges to the program (Tracy, 2010). Initially, regulated parties earned more credits than deficits, creating a huge surplus of banked credits, because compliance could be largely achieved with existing fuel technologies (Fig. 7(a)). As the standard became increasingly stringent, regulated parties started generating more deficits than credits and in the second half of 2017 began drawing down the credit bank. Also in that year, expectations firmed up regarding the extension of the LCFS through 2030, signaling the program's durability and increasing stringency. These factors resulted in higher credit prices after 2017 (Fig. 7(b)).

\subsection{Observations across programs}

Our review of TPS programs indicates that the policies have succeeded in providing flexibility for compliance: companies have pursued different strategies to meet the standards, including selling or purchasing credits and banking. We find substantial amounts of early banking for some programs, since companies expected costs to increase as standards became more stringent, consistent with studies suggesting that banking can both smooth out and lower compliance costs for companies (Rubin and Leiby, 2013; Bialek and Shrader, 2019). Program transparency varies. In RFS and LCFS, fuel and commodities associations publish (unofficial) weekly credit prices that inform their members or customers. In the CAFE and ZEV programs, companies are reluctant to report prices and regulators are reluctant to require reporting because it can reveal commercial information; however, the market is small, major players are visible, and in the ZEV program, direct transfer of credits between two parties is reported.

Most of the credit trading programs in the transportation sector are not large enough to support public trading platforms. Instead, trading takes place bilaterally between companies. Reporting of credit prices may or may not be mandatory but reporting the number of credits sold or bought and the credit balance at the end of the compliance period is always mandatory. Credit prices that are not reported can sometimes be calculated from companies' annual financial reports. Some commodity trading companies that specialize in these markets also report credit prices as part of the market reports for current and potential clients. Table 2 summarizes these TPS programs.

The observed credit prices of TPS programs reflect the stringency level of standards and other factors mentioned above. Credit prices, 
(a)

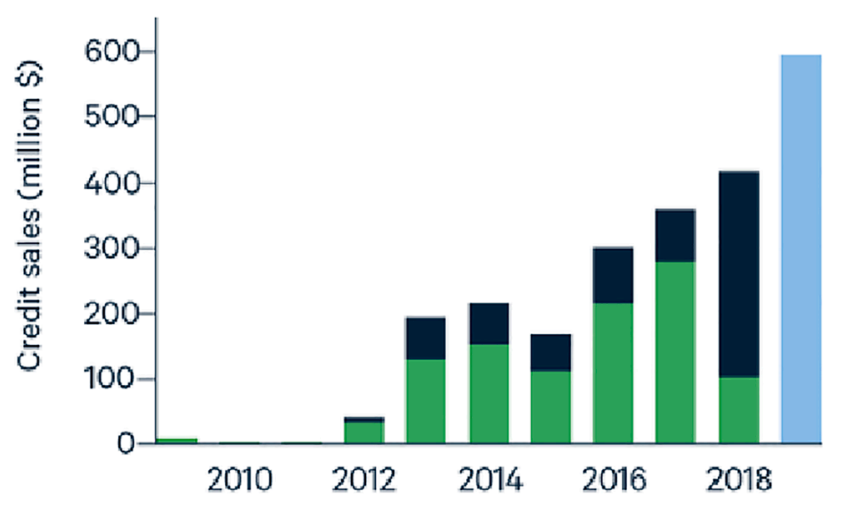

(b)

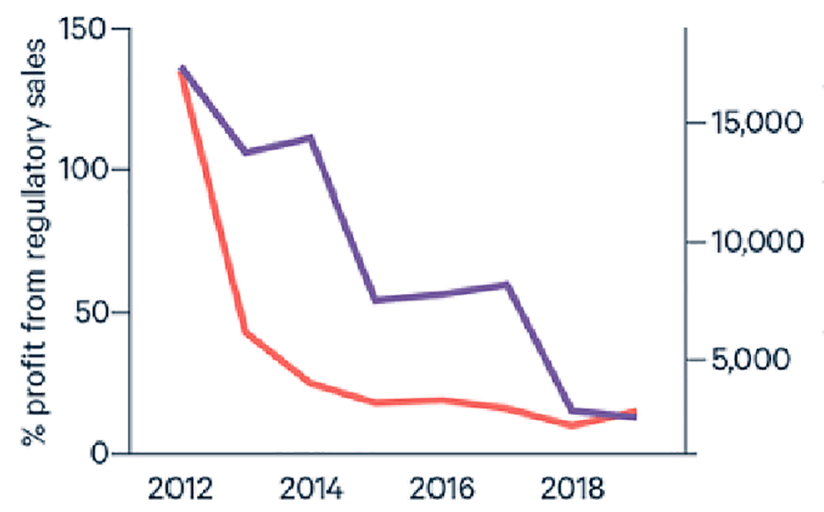

however, are not directly comparable with a price on carbon implemented through an emissions fee or cap-and-trade, or with each other, given that the primary objective of these programs is encouraging innovation and system transition. Viewed in terms of cost per ton of avoided carbon emissions (Section 4.1), observed credit prices are typically higher than in carbon pricing programs globally, but the levels are anticipated to be temporary, and technology benefits are expected to spill over to transportation markets in other countries. The programs simultaneously address other objectives, including energy security, local air quality, and (in the case of US ethanol) agricultural support, and they may yield savings due to the energy efficiency paradox. Nevertheless, given the importance of GHG emissions reductions, below we compare and illustrate the difference between TPS and carbon pricing at the conceptual level (Section 3), and then look at simulation studies that examine the cost and effectiveness of these two approaches individually and at the system level (Section 4).

\section{Carbon pricing versus tradable performance standard}

In this section, we briefly compare carbon pricing with a TPS formulated as a tradable emissions intensity standard to show how these policy approaches relatively affect the product price, technology choice, and the incentive to invest in innovation. An important consideration is how a change in factor prices, including the introduction of a price (or shadow price) on carbon emissions, is passed through to the final price of the product. There are many reasons that the cost pass-through could be less or greater than the value of the (shadow) price introduced by a policy. The economic incidence and statutory incidences do not always coincide, what matters is the relative elasticities of supply and demand and the degree to which the markets are competitive. In one example, Sallee (2011) finds that tax credits for the Toyota Prius were fully passed
Fig. 4. Tesla ZEV and GHG credit sales activity and value.

(a) Tesla's annual regulatory credit sales, 2009-2019. Credit sales data for 2019 (blue bar) were not reported separately as ZEV vs. GHG credit. (b) The annual gross profit from credit sales in percentage and in dollars per vehicle (\$/veh) (right vertical axis), 2012-2018. Sources: Tesla's annual SEC Form 10-k filings and investor reports; authors' own estimates. The estimates are approximate because the cutoff dates are different for sales ( $\$$ millions, January 1 to December 31) and ZEV credit generation (September 1 to August 31 the following year). For example, no ZEV credit sales were reported to CARB in 2018 (September 1, 2018, to August 31, 2019) but $\$ 103.4$ million was reported for January 1-December 31, 2018) to the SEC. Shifting the overlapping years between these data will change the annual estimates but not the overall ranges nor trends. (For interpretation of the references to color in this figure legend, the reader is referred to the web version of this article.)

- \% of gross profit

-\$/vehicle

through to consumers. Other studies also found a complete (Knittel et al., 2017; Burkhardt, 2019), partial (Lade and Bushnell, 2019) or mixed (Erutku, 2019) pass-through of carbon pricing and RIN costs to gasoline and biofuels with substantial heterogeneity, "with the retailers' market structure influencing both the speed and level of pass-through" (Lade and Bushnell, 2019).

Costs pass-through depends on: (i) the relative elasticity of supply to demand; and (if there is market power) (ii) the degree of market power and demand curvature. Since market power would occur at the wholesale or retail level and most fuels are blended, demand elasticities would be the same across the two policies. The only theoretical reason for differential pass-through of TPS versus cap-and-trade (CAT) credits would be on the supply elasticity side. This would occur if the supply elasticity of renewables is different from the supply elasticity of diesel/ gasoline. In this case, the subsidy portion of the TPS credit may be passed-through differently. However, there is little reason to believe pass-through would be different across the two types of credits. Therefore incomplete cost pass-through would not change the results as long as both a carbon pricing and TPS lead to comparable degrees of passthrough to consumers. ${ }^{7}$ In other words, intensity standard versus carbon pricing tradeoff determines the magnitude of the obligation (credit) and that industry characteristics (e.g. supply and demand elasticity, competitiveness) determine the passthrough of an obligation/credit of any particular magnitude.

Consider two fuels - high-carbon fuel (dirty technology, DT, such as gasoline) and low-carbon fuel (clean technology, CT, such as ethanol)-

\footnotetext{
${ }^{7}$ Li et al. (2014) find that the same change in product prices may stimulate different changes in consumer behavior based on the source of the price change (fuel prices versus gas taxes).
} 
(a)

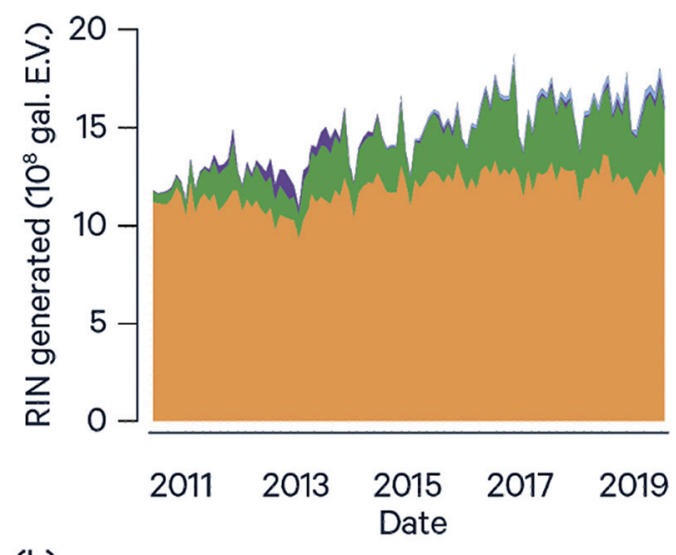

Fig. 5. Shares, price trends, and emissions of renewable fuels.

(a) Renewable identification number (RIN, or credit) generated by fuel type, 2010-2019, measured as equivalence value (EV). The $\mathrm{EV}$ of a renewable fuel represents the number of gallons that can be claimed for compliance purposes for every physical gallon of renewable fuel used, and it is generally the ratio of the energy content of a gallon of the fuel to a gallon of ethanol. (b) RIN prices by fuel type, 2010-2019, and maximum allowable lifecycle GHG emissions relative to gasoline or diesel for each fuel category. Source: US Environmental Protection Agency (EPA) (2019).

(6)

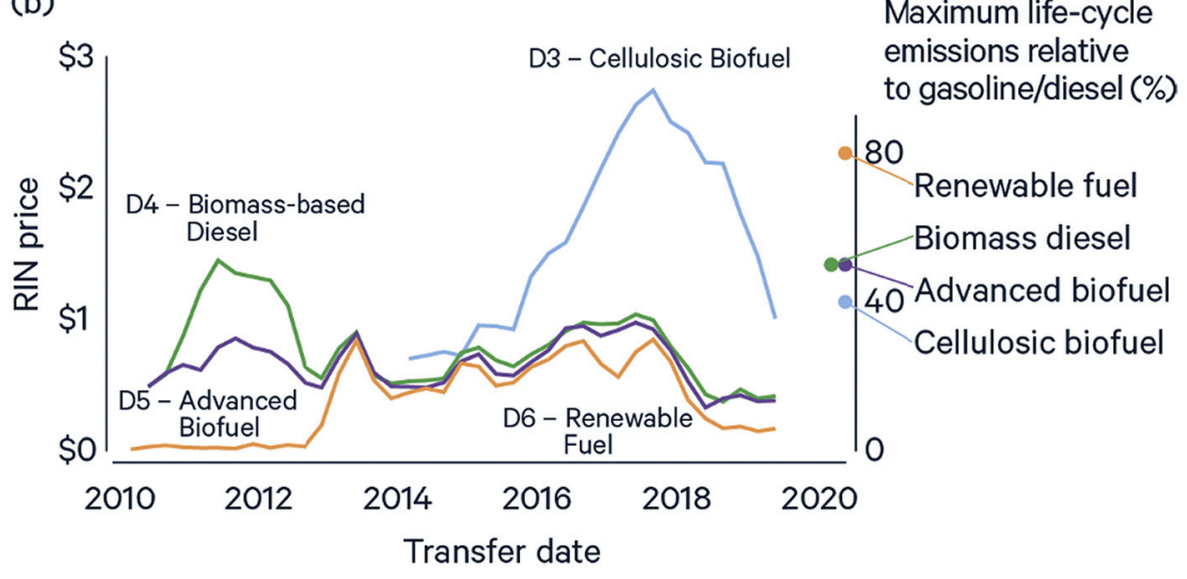

(a)

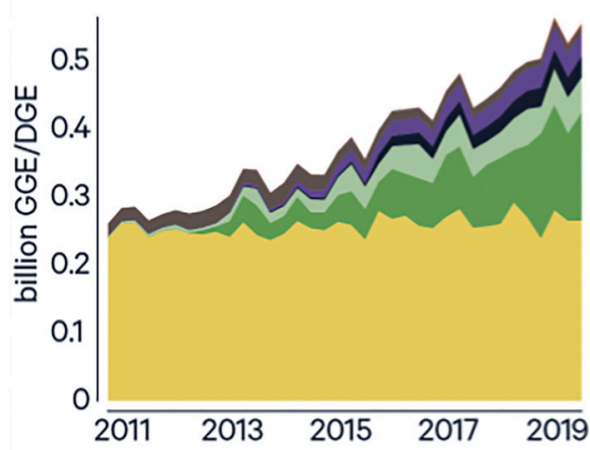

(b)

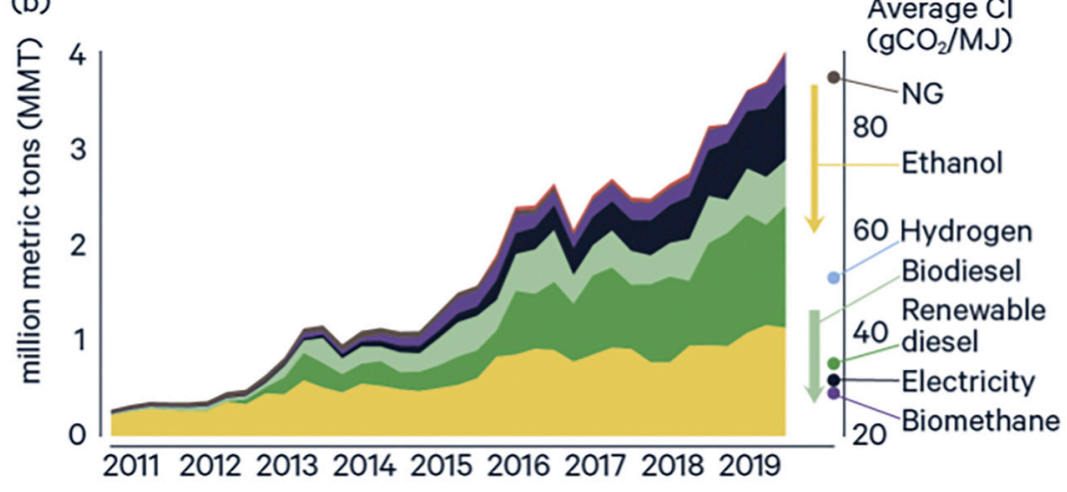

Fig. 6. Alternative fuel volumes and California LCFS credits, by fuel type.

(a) "Other" includes hydrogen, renewable naphtha, and propane. Ethanol, electricity, and other fuel volumes are in gasoline gallon equivalent (GGE); natural gas, biomethane, biodiesel and renewable diesel are in diesel gallon equivalent (DGE). The arrows in (b) suggest 33 and $41 \%$ reductions in the lifecycle CI of ethanol and biodiesel, respective, throughout the program. Sources: California Air Resources Board (CARB). (2020a); pers. Commun., J. Witcover, Institute of Transportation Studies, University of California, Davis, May 232,020 . 
(a)

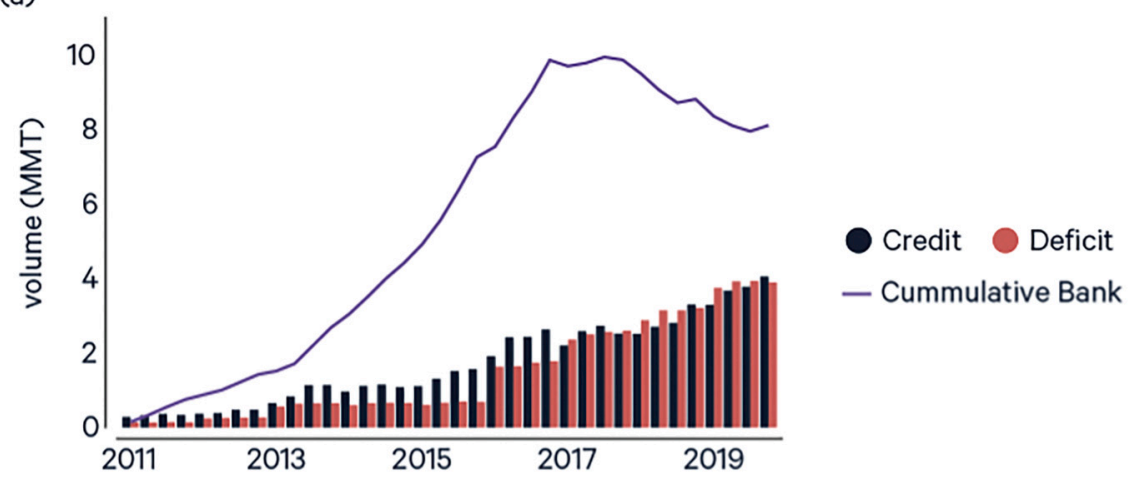

(b)

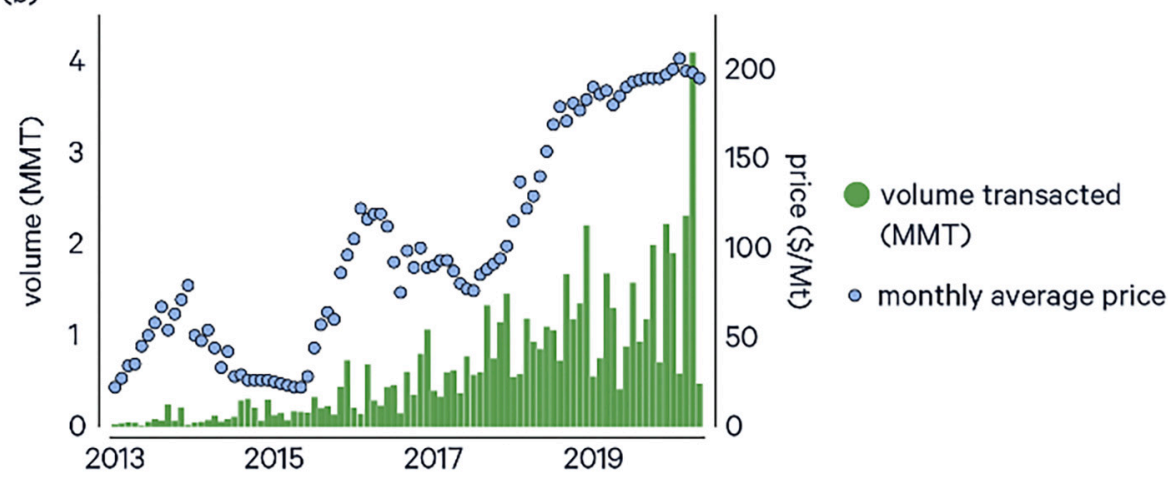

Fig. 7. California LCFS credits, deficits, sales, and price trends, 2011-2019.

(a) Total LCFS credits and deficits reported by year and cumulative credit bank, 2011Q1-2019Q1. Sources: Witcover (2018); California Air Resources Board (CARB). (2020a). (b) Volumes of LCFS credit transactions (left axis) and LCFS credit price (right axis), 2013-2019. Source: California Air Resources Board (CARB). (2020a).

Table 2

Selected tradable performance standards in US transportation sector.

\begin{tabular}{|c|c|c|c|c|}
\hline Program & GHG emissions regulations for vehicles ${ }^{a}$ & Zero-emission vehicle (ZEV) ${ }^{\mathrm{a}}$ & $\begin{array}{l}\text { Renewable fuel standard } \\
\text { (RFS) }\end{array}$ & $\begin{array}{l}\text { Low carbon fuel standard } \\
\text { (LCFS) }\end{array}$ \\
\hline Jurisdiction & National & California, 9 other states & National & California, Oregon \\
\hline Regulated party & Vehicle manufacturers, importers & Vehicle manufacturers, importers & Fuel producers, importers & $\begin{array}{l}\text { Fuel producers, } \\
\text { importers }\end{array}$ \\
\hline Aims & $\begin{array}{l}\text { To improve vehicle fuel economy, reduce } \\
\text { GHG intensity }\end{array}$ & To increase sales of electric vehicles & To increase sales of biofuels & $\begin{array}{l}\text { To reduce fuels' GHG } \\
\text { intensity }\end{array}$ \\
\hline Design & $\begin{array}{l}\text { Emissions intensity standard }\left(\mathrm{gCO}_{2} \mathrm{e} /\right. \\
\text { mile) }\end{array}$ & $\begin{array}{l}\text { Volumetric mandate based on sales } \\
\text { volumes (number of ZEVs) }\end{array}$ & $\begin{array}{l}\text { Volumetric mandate based } \\
\text { on sales volumes }\end{array}$ & $\begin{array}{l}\text { Emissions intensity } \\
\text { standard }\left(\mathrm{gCO}_{2} \mathrm{e} / \mathrm{MJ}\right)\end{array}$ \\
\hline Credit labels & GHG credit & ZEV credit & $\begin{array}{l}\text { Renewable identification } \\
\text { number (RIN) }\end{array}$ & LCFS credit \\
\hline $\begin{array}{l}\text { Credit generation } \\
\text { mechanism }\end{array}$ & $\begin{array}{l}\text { Megagrams }(\mathrm{Mg}) \text { or equivalent metric } \\
\text { tons of } \mathrm{CO}_{2} \mathrm{e} \text { below manufacturer's } \\
\text { required standard }\end{array}$ & $\begin{array}{l}\text { Battery electric and fuel-cell vehicles } \\
\text { receive } 1 \text { to } 4 \text { credits, based on driving } \\
\text { range }\end{array}$ & $\begin{array}{l}\text { Gallon of gasoline or diesel } \\
\text { equivalent }\end{array}$ & $\begin{array}{l}\text { Metric tons of } \mathrm{CO}_{2} \mathrm{e} \\
\text { reduction below the } \\
\text { standard }\end{array}$ \\
\hline $\begin{array}{l}\text { Reported or estimated } \\
\text { credit prices in program's } \\
\text { own unit }^{\text {b }}\end{array}$ & $\$ 10-\$ 63 / \mathrm{MgCO}_{2} \mathrm{e}$ & $\$ 1000-\$ 7000 / Z E V$ credit (California) & $\$ 0.02-\$ 2.45 /$ RIN credit & $\begin{array}{l}\$ 25-\$ 200 / \mathrm{tCO}_{2} \mathrm{e} \\
\text { (California) }\end{array}$ \\
\hline $\begin{array}{l}\text { Estimated carbon } \\
\text { mitigation costs }\end{array}$ & $\$ 10-\$ 63 / \mathrm{tCO}_{2} \mathrm{e}$ & $\$ 82-\$ 320 / \mathrm{tCO}_{2} \mathrm{e}$ & $\$ 20-\$ 52 / \mathrm{tCO}_{2} \mathrm{e}$ & $\$ 25-\$ 200 / \mathrm{tCO}_{2} \mathrm{e}$ \\
\hline $\begin{array}{l}\text { Credit generation starting } \\
\text { date }\end{array}$ & Early credit 2009-2011; trading in 2012 & 2009 & 2010 & 2011 \\
\hline Sales volume $(\$)^{\mathrm{b}}$ & $\$ 1.7$ billion (2012-2015) & $\begin{array}{l}\text { Tesla sold } \$ 1.04 \text { billion in ZEV credits } \\
(2009-2018) \text {, or } 68 \% \text { of all ZEV credits for } \\
2012-2018\end{array}$ & $\begin{array}{l}\$ 76.2 \text { billion based on } \\
\text { generated RINs } \\
(2010-2019 Q 3)\end{array}$ & $\begin{array}{l}\$ 8.3 \text { billion (2013-2020 } \\
\text { May) }\end{array}$ \\
\hline
\end{tabular}

a Programs started as technology mandates or standards and incorporated credit trading later.

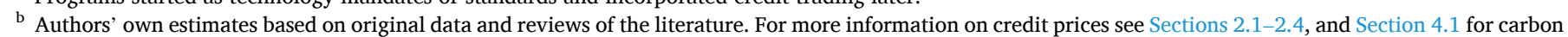
mitigation costs.

that have respective carbon intensities above and below an emissions intensity standard, $\mathrm{C}_{\mathrm{DT}}>\mathrm{C}_{\mathrm{S}}>\mathrm{C}_{\mathrm{CT}}$, where

$S, C T)$.
$\mathrm{E}_{D T}$ : energy content of DT (MJ/liter)

$\mathrm{P}_{j}$ : carbon tax price and intensity standard credit price $\left(\$ / \mathrm{gCO}_{2}\right)(j=$ $T, S)$

$\Delta P_{j}^{D T}$ : change in price of DT under a tax or standard (\$/liter DT). 
$\Delta P_{j}^{C T}$ : change in price of CT under a tax or standard (\$/liter DT).

We use gasoline and ethanol as examples. Because ethanol has less energy content than gasoline, we do all the accounting for ethanol in liters of gasoline equivalent, which is established by measuring each fuel in energy content (megajoules, MJ). ${ }^{8}$

\subsection{Effect of carbon pricing on fuel prices}

The effect of a carbon price, implemented as a carbon tax or through emissions cap-and-trade, is to add a cost component corresponding to the carbon emissions of a fuel ${ }^{9}$ (emissions multiplied by the carbon price level) to the fuel price. ${ }^{10}$

The emissions from ethanol are typically lower than emissions from gasoline, and hence the price of ethanol rises less than the price of gasoline. Under a carbon price, (henceforth called tax), the increment to the price per liter of gasoline and ethanol depends on the carbon tax, the carbon content of the fuel and $\rho$ the pass-through factor:

$\Delta \mathrm{P}_{\mathrm{T}}^{\mathrm{DT}}=\mathrm{P}_{\mathrm{T}} \times \mathrm{C}_{\mathrm{DT}} \times \mathrm{E}_{\mathrm{DT}} \times \rho$

$\Delta \mathrm{P}_{\mathrm{T}}^{\mathrm{CT}}=\mathrm{P}_{\mathrm{T}} \times \mathrm{C}_{\mathrm{CT}} \times \mathrm{E}_{\mathrm{DT}} \times \rho$

The emission from CT is lower than from DT, and hence the change in the price of CT per liter of DT equivalent rises less than the price of DT. ${ }^{11}$ The change in the relative prices of the fuels, given by the difference in their carbon intensities, provides an incentive for the use of CT over DT. We call this the incentive margin (IM) under a carbon tax for producing a liter of alternative fuel:

$I M_{T}=P_{T} \times\left(\mathrm{C}_{D T}-C_{C T}\right) \times \mathrm{E}_{D T} \times \rho$

\subsection{Effect of tradable intensity standards on fuel prices}

Tradable intensity standards and taxes have different effects. A tax raises the prices of both fuels, but more for gasoline. An intensity standard will raise the price of dirty fuel just a bit but lower the price of the clean fuel. It works by requiring that fuels have an average emissions intensity of $C_{S}$. Producers of fuel with higher emissions intensity need to buy credits, and producers of fuel with lower emissions intensity earn credits that can be sold. In our example, in effect, credit payments by DT serve as a production incentive for CT (and other low-carbon fuels).

The price changes for DT and CT under the tradable intensity standard are given by (3).

$\Delta \mathrm{P}_{\mathrm{S}}^{\mathrm{DT}}=\mathrm{P}_{\mathrm{S}} \times\left(\mathrm{C}_{\mathrm{DT}}-\mathrm{C}_{\mathrm{S}}\right) \times \mathrm{E}_{\mathrm{DT}} \times \rho$

$\Delta \mathrm{P}_{\mathrm{S}}^{\mathrm{CT}}=\mathrm{P}_{\mathrm{S}} \times\left(\mathrm{C}_{\mathrm{CT}}-\mathrm{C}_{\mathrm{S}}\right) \times \mathrm{E}_{\mathrm{DT}} \times \rho$

\footnotetext{
8 The energy content of ethanol is about two-thirds that of gasoline, $24 \mathrm{MJ} / 1$ versus $34 \mathrm{MJ} / \mathrm{l}$.

${ }^{9}$ We assume the carbon price is applied over the full lifecycle, though in real policy applications this is not always the case. In contrast, the LCFS accounts for emissions across the entire lifecycle for each fuel. These two approaches reflect the system boundaries of the two policies and have significant implications in terms of leakage. See DeCicco (2012) for a discussion of the trade-offs.

${ }^{10}$ Here we have assumed the conventional structure of a tax: the user pays a tax on each unit of emissions. This need not be the case. A different outcome would result if the policymaker allowed a certain amount of pollution for free and charged only for the excess pollution (Pezzey and Jotzo, 2013). This possibility is rarely (if ever) used, but it would make the tax similar in some respects to a tradable intensity standard. The same result as for a tax would be achieved in a carbon trading scheme where allowances were distributed using output-based allocation of emissions allowances (Fischer, 2019), a practice that is observed for a portion of the market in the EU, California, and Quebec trading programs.

11 It is often the case, however, that biofuels (e.g. ethanol) are treated as "carbon neutral" under cap-and-trade programs and therefore do not pay a carbon price.
}

We calculate the incentive margin for producing a liter of lower carbon fuel under a tradable intensity standard as the difference in prices for DT and CT:

$I M_{S}=P_{S} \times\left(\mathrm{C}_{D T}-C_{C T}\right) \times \mathrm{E}_{D T} \times \rho$

Note that $I M_{S}$ and $I M_{T}$ are of the same functional form and would be identical for the case that $P_{S}=P_{T}$. Since $\rho$ applies to both policies equally (and assuming that the pass through would be the same for both instruments), it is dropped for simplicity in the rest of the paper. It is also interesting that $C_{S}$ is absent in Eq. (4); that is, the incentive margin of the tradable intensity standard $I M_{S}$ is only indirectly related to the level of standard through the credit prices. The more stringent the intensity standard, the higher the credit price, and therefore the higher the incentive margin.

We illustrate in Fig. 8 that under a carbon tax, both high-carbon fuel (dirty technology, DT, such as gasoline) and low-carbon fuel (clean technology, CT, such as ethanol) are penalized by higher prices, whereas under the tradable intensity standard, the low-carbon fuel receives a "reward" instead. Importantly, when the carbon tax price $\left(P_{T}\right)$ and intensity standard credit price $\left(P_{S}\right)$ are equal, $P_{S}=P_{T}$, the changes in fuel prices (both positive and negative) are much smaller under an intensity standard, since the price change is only the credit price multiplied by the difference between the standard, $C_{S}$, and the carbon intensity of the fuel, $\left(C_{D T}-C_{S}\right.$ and $\left.C_{C T}-C_{S}\right)$, whereas the price change under a carbon tax is the credit price multiplied by the full carbon intensity of the fuel or technology $\left(C_{D T}\right.$ and $\left.C_{C T}\right)$. Subsequently, the average price of both fuels is lower under an intensity standard than with revenue-raising carbon taxation because payments are made and received within the sector, i.e., no revenue leaves the sector to go to government (Rajagopal et al., 2011). This is good news for motorists (and may explain why this instrument is often favored by policymakers). However, it also means that the incentive to economize on miles driven will be weaker-this weak output effect is a source of inefficiency in a TPS system relative to a tax.

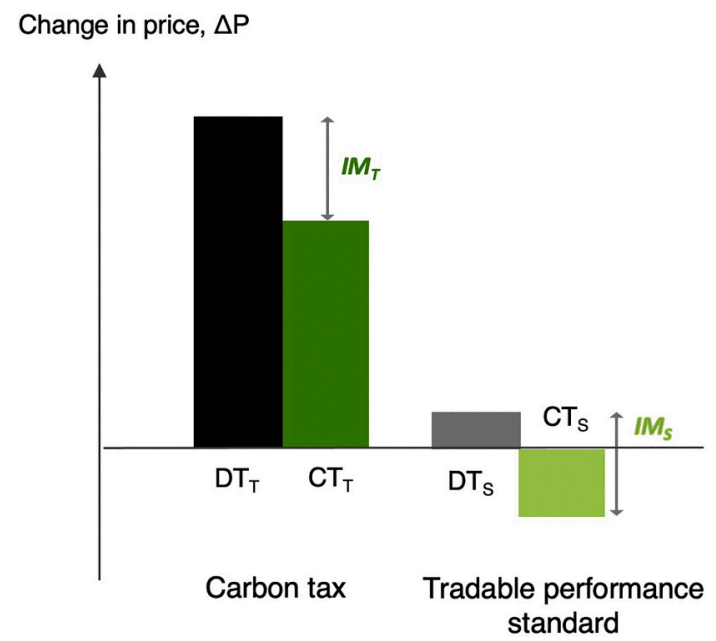

Fig. 8. Price change of dirty and clean technology under carbon tax and tradable intensity standard.

Price change of two products (a dirty technology, DT, and a clean technology, $\mathrm{CT}$, with equivalent energy content) under a carbon price (T) or credit price under an intensity standard (S), and the incentive margins of a carbon $\operatorname{tax}\left(\mathrm{IM}_{\mathrm{T}}\right)$ vs. a performance standard $\left(\mathrm{IM}_{\mathrm{S}}\right)$ for an equivalent carbon and standard price level, $P_{T}=P_{S}=P$. A negative value means a technology receives subsidies under the program, and a positive value means the program increases the price of a technology. For reference, the carbon price in California was around \$17/ $\mathrm{tCO}_{2} \mathrm{e}$ and LCFS credit price was around $\$ 200 / \mathrm{tCO}_{2} \mathrm{e}$ in the first half of 2020 , translating to about equal level of IM. Though the figures are intended to be illustrative (therefore the vertical axes are not labeled), the figures are scaled realistically, using realistic assumptions of gasoline $\mathrm{C}_{\mathrm{DT}}=100 \mathrm{gCO}_{2} \mathrm{e}$, ethanol $\mathrm{C}_{\mathrm{CT}}=60 \mathrm{gCO}_{2} \mathrm{e}$ with the standard set at $90 \mathrm{gCO}_{2} \mathrm{e}(10 \%$ below gasoline $\mathrm{CI})$. 
As we discuss in Section 4, both a carbon price (through cap and trade) and tradable emissions intensity standards including the LCFS and ZEV programs are implemented simultaneously in California. The LCFS credit price is about ten times greater than the carbon price $\left(P_{S}=\right.$ $10 \times P_{T}$ ), and generates an incentive to switch from dirty to clean fuel that is about 10 times greater. However, the change in the product price viewed by consumers attributable to each program is about equal (around 20 cents per gallon). The effects of the two policies on the incentive to produce alternative fuels and on the change in fuel prices are roughly additive.

We make two important observations. First, the incentive to produce alternative fuel instead of gasoline expressed as $I M$ (included implicitly in a carbon tax program or explicitly in a performance standard program) is a function solely of the carbon tax or credit price across both programs. n California, we observe that CAT has lower values per ton carbon, and therefore weaker incentives for technology switching, than TPS programs.

Second, because emissions pricing puts an equal value on emissions reductions through changes in technology or through reduced consumption of goods that embed emissions, it is equivalent to a coupled performance standard program and consumption tax, where the credit and tax prices have a fixed relationship with each another. Because a performance standard focuses on producers and a consumption tax affects consumers, policymakers wishing to increase the effect of technology switching by producers could consider decoupling these two aspects of a carbon tax. Although any deviation away from a pure carbon tax would be less efficient economically, a decoupling may foster greater technology innovation by producers without transmitting an equivalent change in product prices to consumers. In the industrial sector context, this decoupling may help maintain industry's overall market share amid international competition during a transition until technical, political, and societal factors allow for greater levels of a consumption tax (Pollitt et al., 2020). As we discussed above, incomplete costs passthrough as a result of supply and demand elasticity and industry competitiveness may change the magnitude of the obligation (credit) to a similar degree.

\section{Effects on GHG emissions reductions}

As emphasized previously, the most important objective of TPS is not GHG emissions reductions but other societal benefits-energy transition, energy efficiency, clean air, energy security, agricultural jobs-that lower the cost of clean(er) technology over time. The cost estimates also differ, depending on a static versus dynamic view of the program and the system-level interactions that are taken into account. For example, the GHG reduction from one ZEV credit depends on what vehicle the alternative vehicle replaces, the system-level effects of the program such as emission leakages and rebound, and the effects of complementary or overlapping policies (Mansur et al., 2016). In this section, we evaluate the cost-effectiveness of individual TPS programs in terms of the empirically observed carbon abatement cost ( $\$ /$ ton $\mathrm{CO}_{2} \mathrm{e}$ abated) (Section 4.1). We review studies that examine the effects of the programs in isolation (Section 4.2), the interactions of TPS programs (Section 4.3), and the effects of a TPS program within a cap-and-trade program (Section 4.3).

\subsection{Carbon mitigation costs}

Given the various policy targets, the units of TPS credits vary (as summarized in Table 2 and discussed in detail in Section 3). For example, GHG regulations for vehicles have a credit price of \$10-63/ $\mathrm{MgCO}_{2} \mathrm{e},{ }^{12}$ the LCFS credit price is around $\$ 200$ per credit $\left(\mathrm{tCO}_{2} \mathrm{e}\right), \mathrm{RFS}$ RIN credits range from $\$ 0.02$ to $\$ 2.24$ per RIN (equivalent value of biofuel gallon), and ZEV credits range from $\$ 1000$ to $\$ 7000$ per credit

\footnotetext{
$\overline{12} 1 \mathrm{Mg} \mathrm{CO}{ }_{2} \mathrm{e}=1$ metric ton (t) $\mathrm{CO}_{2} \mathrm{e}$.
}

(Table 1). The GHG regulations for vehicles credit price of $\$ 63 / \mathrm{Mg}$ $\left(\$ 63 / \mathrm{tCO}_{2} \mathrm{e}\right.$ ) and the LCFS credit price of $\$ 200 / \mathrm{tCO}_{2} \mathrm{e}$ can both be taken directly as the marginal mitigation cost of GHG abatement. At $\$ 1000$ $\$ 7000$ per ZEV credit, the marginal mitigation cost of ZEV is $\$ 82-\$ 560$ / $\mathrm{tCO}_{2} \mathrm{e} .{ }^{13}$ Simulation studies suggest RFS2 compliance costs are likely to range between $\$ 20-\$ 52 / \mathrm{tCO}_{2} \mathrm{e}$ (Chen et al., 2014; Johansson et al., 2020). These illustrative estimates are consistent with the static cost estimates reviewed in Gillingham and Stock (2018).

\subsection{Effects of TPS programs in isolation}

Several studies find that CAFE has altered manufacturers' vehicle offerings and consumers' purchase decisions (Greene, 1998; Michalek et al., 2005; Fischer, 2010). Various studies identify an emissions rebound from increased consumption because efficiency improvements lower the cost of travel (Ross Morrow et al., 2010), though the size of rebound is debated in the literature (Small and Van Dender, 2007; Hymel et al., 2010; Greene, 2012; Hymel and Small, 2015; Dimitropoulos et al., 2018). Nevertheless, the fuel economy standards' reduction in GHG emissions has been substantial. Greene et al. (2020) estimated that efficiency improvements to US light-duty vehicles reduced GHG emissions by 17 billion metric tons; the standards were identified as responsible for more than $80 \%$ of the improvements, and fuel prices changes, less than $20 \%$ (partly because of low fuel prices in the United States). However, the new footprint-based vehicle GHG standard could trigger a rebound effect stemming from the distorted incentives toward larger vehicles for manufacturers and consumers (Ito and Sallee, 2017).

Similarly, studies find that the ZEV program has altered manufacturers' ZEV production (Collantes and Sperling, 2008; Wesseling et al., 2014, 2015; Jenn et al., 2019). Using data on patents, sales, and political activity, studies find that manufacturers also chose political strategies that evolved over time from value maintenance (minimize research and development, oppose the policy) to value creation (invest heavily in research and development to occupy the new market, proactively attempt to influence the policy) (Wesseling et al., 2014, 2015).

Many studies have looked at the effects of RFS (de Gorter and Just, 2010; Schnepf and Yacobucci, 2013; National Research Council (NRC), 2011; Farzad and Tyner, 2014) and LCFS (Yeh et al., 2009; Holland et al., 2009; Yeh and Sperling, 2010; Huang et al., 2013). The policies incentivized large amounts of grain-based biofuels from corn and soybean, but both fell short of incentivizing very low carbon biofuels, such as biofuels from cellulosic biomass or advanced technologies like "dropin" biofuels. However, consistent with the LCFS incentives, we observe under the LCFS compliance pathways an evolution toward reducing the lifecycle emissions of biofuels and increasing the contribution from nonbio-based alternative fuels (Fig. 6). The more complicated questions are the net GHG emissions reductions and the interactions of the two policies. Two controversies surround the effects GHG reductions: (1) increased fuel consumption and incomplete petroleum displacement due to the (global) fuel market rebound effect (Rajagopal et al., 2011; Hill et al., 2016), and (2) indirect land-use change due to leakage when increased demand for crop-based biofuels leads to cropland expansion and forest clearance that increase GHG emissions (Tilman et al., 2009; National Research Council (NRC), 2011).

\subsection{Interactive effects: complementary, overlapping, or sequencing?}

The success of performance standards critically depends on their interaction with other policy packages. This interaction is complementary in addressing long-term, large-scale energy transitions, in several

\footnotetext{
13 Assumptions: EV runs $1.6 \mathrm{~km} / \mathrm{MJ}$ and an average gasoline car runs $0.5 \mathrm{~km} /$ $\mathrm{MJ}$; electricity $\mathrm{CI}=200 \mathrm{gCO}_{2} \mathrm{e} / \mathrm{MJ}$ (California grid); a vehicle is driven 19,200 $\mathrm{km}$ annually for 15 years.
} 
ways. For instance, a ZEV policy does not stand on its own in promoting clean transportation technology: other policies provide subsidies directly to consumers (Sen et al., 2017; Münzel et al., 2019), subsidize investment in charging stations (Peterson and Michalek, 2013) and hydrogen refueling stations for electric vehicles (Ogden, 1999), encourage changes to laws and regulations on station design and siting (among other institutional changes), inform potential vehicle purchasers and reduce risk aversion to new technologies, subsidize R\&D, and seek to lower electricity emissions. Additionally, the more successful ZEV and RFS are, the easier it is to achieve the LCFS because the adoption of lowcarbon vehicles and fuels expands and enhances the compliance options. All these programs promote the adoption of clean vehicles and fuels, but LCFS provides additional incentives to lower the emissions intensity of alternative fuels.

However, a combination of policies can also lead to undesirable consequences. For example, Jenn et al. (2019) simulate the interactive effect of CAFE and ZEV policies and find that the combined policies produce higher GHG emissions than either policy alone. This is because ZEV sales allow for the greater sale of less fuel efficient gasoline and diesel vehicles in the presence of a binding CAFE standard. Complementarity requires, preferably, automatic program adjustments and reviews of policy targets given interactions with other policies.

\subsection{TPS programs combined with carbon pricing}

In California, cap-and-trade (CAT) is implemented alongside other regulations and policies to reduce overall emissions (Sperling and Nichols, 2012). California's CAT Phase I compliance period (effective January 1,2013 ) placed a cap on GHG emissions associated with electricity consumption (for electricity both generated in the state and imported) and large industrial sources in the state, including refineries. Starting January 1, 2015, the CAT policy was expanded to include GHG emissions from on-road transportation fuels, covering gasoline, diesel, and natural gas but exempting carbon emissions from biofuels. The CAT and the TPS programs are designed to address separate challenges in achieving the state's comprehensive climate goal. One challenge is the carbon price is insufficiently high to achieve the kind of rapid technological innovation necessary for energy transformation and deep GHG emissions reductions in an ambitious timeline. TPS programs are partially intended to remedy this challenge.

TPS and carbon pricing policies could also have other interactions in terms of compliance and effects on both regulated parties and consumers. California's regulated parties have several compliance obligations (Table 1) in addition to CAT. For vehicle manufacturers and importers, regulations for GHG emissions from passenger cars and trucks and ZEV are additive ("stackable"), and meeting the ZEV program will help with meeting the regulations for GHG emissions, but not vice versa (Sen et al., 2017). As shown in Fig. 4, Tesla profited from selling regulatory credits, including both ZEV credits and GHG credits. Similarly, for fuel producers and importers, meeting the RFS will help with meeting the LCFS targets. Renewable fuel producers and providers will receive credits from both RFS and LCFS, and compliance will reduce the obligations under the CAT if the obligated party is a fossil fuel provider.

As an example, Fig. 9 uses realistic assumptions in California to illustrate the credit values per gallon for two representative fuel types, gasoline and very low carbon biofuel, and the additive effects of LCFS, CAT, and RFS (the example works similarly for diesel fuel and its substitutes). The incentive margin of the fuel market is the sum of the penalties on fossil fuels plus incentives for biofuel. The additive effect remains large, given the rising penalties on gasoline (and diesel) despite the shrinking values of the incentives for biofuel over time. The combined effect is substantially greater than the incentive margin provided by carbon pricing from the CAT alone. For example, in 2020 biofuel received a net subsidy of $\$ 3.0 / \mathrm{GGE}$, and gasoline incurred a penalty of $\$ 0.37$ per gallon. Under the three programs, the net cost per average gallon of gasoline (E10) bought by consumers was a net subsidy of $\$ 0.1$ per gallon in 2020. In 2030 the subsidy to biofuel of the same carbon intensity falls to $\$ 2.7 / \mathrm{GGE}$ (assuming the same credit price) and the penalty on gasoline increases to $\$ 0.93$ per gallon, for a net cost of $\$ 0.2$ per gallon of blended gasoline to consumers.

Many observers argue for complementary CAT (or carbon pricing generally) and regulatory policies in the presence of imperfect markets (Bird et al., 2011) or learning spillovers (Fischer and Preonas, 2012; Lehmann, 2013). For example, energy-efficient technologies, a critical component of the transition to sustainable energy (GEA, 2012), are often hindered by the energy efficiency paradox, a behavioral issue. Whether consumers undervalue the future savings from energy efficiency improvements (termed "internalities" by Allcott et al., 2014) and if so, to what extent, is a subject of ongoing debate and research (Gillingham and Palmer, 2014; Gerarden et al., 2015). If behavioral issues are prevalent, then pricing inefficiency through a combination of energy efficiency incentives, along with a direct tax or shadow price induced by an equivalent TPS, may be a necessary component of an economically efficient policy solution (Allcott et al., 2014; Heutel, 2015).

The variation in marginal costs and other incentives across these policies, however, creates inefficiency and, inevitably, forgone opportunities for emissions reductions that could be remedied through carbon pricing. This inefficiency may be necessary due to the high political cost of trying to implement carbon prices at levels recommended by economic theory, and a combination of modest carbon prices with performance standards will cost less than a standard-only policy that reduces the same amount of emissions (Dimanchev and Knittel, 2020). In the

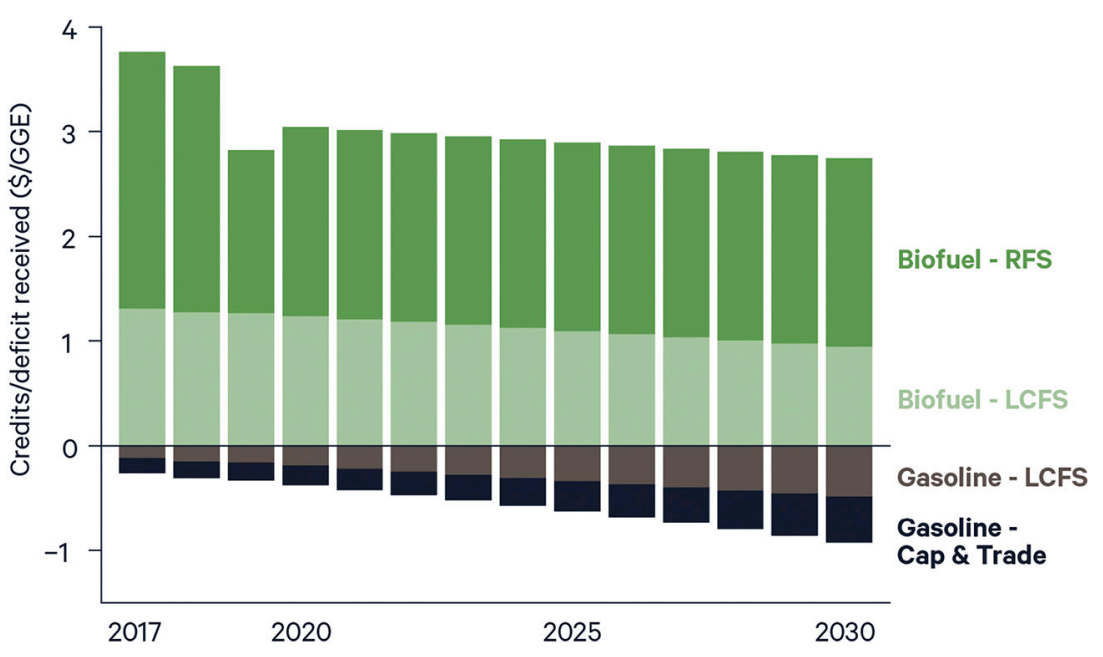

Fig. 9. Additive effects of policies in California's fuel market, 2017-2030.

The effects on gasoline are shown in black (CAT) and gray (LCFS), and the effects on low-carbon biofuels are shown in dark green (RFS) and light green (LCFS). Positive values imply that a product receives credits, whereas negative values imply that a product incurs penalties. We use the realistic assumptions of credit prices described in Section 4: LCFS \$200/credit, CAT carbon price from $\$ 15 / \mathrm{tCO}_{2} \mathrm{e}$ in 2017 to $\$ 50 / \mathrm{tCO}_{2} \mathrm{e}$ in 2030, cellulosic biofuels RIN historical values (2017-2020) and $\$ 1.8 /$ gal after 2020. The carbon intensity of biofuel $=40$ $\mathrm{gCO}_{2} \mathrm{e} / \mathrm{MJ}$. GGE means gasoline gallon equivalent. Gasoline has on average $119.5 \mathrm{MJ} /$ gal, and ethanol $=81.5 \mathrm{MJ} /$ gal. (For interpretation of the references to color in this figure legend, the reader is referred to the web version of this article.) 
short run, technology forcing programs can have the effect of lowering the effectiveness of carbon pricing under CAT programs through the "waterbed effect" by lowering the demand for allowances, thereby lowering their market price and the induced incentive for innovation in the carbon market (Abrell, 2011; Tsao et al., 2011; Fischer and Preonas, 2012; Nelson et al., 2015). In the California CAT program, the minimum auction price provides an effective price floor that converts reduced demand for allowances into a reduced supply of allowances and reduced emissions. In the long run, innovation-driven policies in the transportation sector can be viewed as a policy sequence that provides an onramp to greater stringency and efficiency through expanded carbon pricing (Meckling et al., 2017; Pahle et al., 2018).

\section{Conclusions}

Tradable performance standards are technology requirements or emissions intensity standards that allow the trading of compliance credits across companies. Unlike pollution pricing, they do not fully internalize the costs of emissions and thus they raise the total cost of emissions reductions compared with pollution pricing. However, they provide incentives for upstream innovation and technology transformation that are greater per dollar change in product prices than carbon pricing and are generally additive to the effects of carbon pricing. That is, the policies can be combined without sacrificing the efficiency properties achieved by pricing.

TPS policies have special appeal in the context of achieving deep decarbonization because of the crucial role of innovation. Reducing GHG emissions enough to limit global warming to $1.5^{\circ}$ or $2.0^{\circ} \mathrm{C}$ requires a global transition from fossil energy. This transition could in principle be achieved with carbon pricing, but the complexity, inherent uncertainty, and systemic nature of the climate challenge would necessitate unrealistically high carbon prices (e.g., Rosenbloom et al., 2020). Comprehensive strategies addressing institutional change, network effects, tipping points, and behavioral issues also appear unreachable except with very high carbon prices. The transition will take decades, so it requires policies that will enjoy sustained public support. TPS policies thus present an attractive alternative, particularly in jurisdictions with strong resistance to fuel taxes (e.g., Heutel, 2020). Moreover, the carbon pricing and TPS strategies are not mutually incompatible.

Two observations provide guidance for policy:

First, the incentive to innovate, which we describe as the incentive margin-whether included implicitly in a carbon tax program or explicitly as a cross-subsidy among technologies in a TPS program-is a function solely of the carbon and credit prices across both policies. We observe empirically that carbon pricing programs tend to have lower prices, and therefore weaker incentives for technology switching, than existing TPS programs. Even with explicitly high fuel taxes in Europe and Japan, the incentives for technology change are still likely to be insufficient to achieve climate policy goals for the transportation sector. In California, where carbon pricing may have approximately the same effect on consumer prices as a TPS, the incentive margin for technology innovation under the TPS is 10 -fold greater.

Second, when combined with a carbon tax, TPS both achieves a high cross-subsidy between technologies to incentivize innovation and provides moderate output effects. TPS policies are intended to function as part of a comprehensive strategy to address long-term, large-scale energy transitions. Their success therefore critically depends on the other, companion policies, including carbon pricing, and care must be taken to ensure that overlapping policies work as intended without creating unintended consequences. With these conditions firmly in place, TPS policies will be, and are now, an important contributor to global decarbonization.

\section{Acknowledgments}

Funding was received from Area of Advance Transport at Chalmers
University of Technology, MISTRA Carbon Exit program from the MISTRA Foundation, and SOF Transport at Gothenburg University.

\section{Appendix A. Supplementary data}

Supplementary data to this article can be found online at https://doi. org/10.1016/j.eneco.2021.105490.

\section{References}

Abrell, J., 2011. Private Transport and the European Emission Trading System: Revenue Recycling, Public Transport Subsidies, and Congestion Effects. https://doi.org/ 10.2139/ssrn.1844300. Available at SSRN. https://ssrn.com/abstract $=1844300$.

Allcott, H., Mullainathan, S., Taubinsky, D., 2014. Energy policy with externalities and internalities. J. Public Econ. 112, 72-88.

Anderson, S., Sallee, J., 2011. Using loopholes to reveal the marginal cost of regulation: the case of fuel-economy standards. Am. Econ. Rev. 101 (4), 1375-1409.

Bergek, A., Berggren, C., 2014. The impact of Environmental policy instruments on innovation: a review of energy and automotive industry studies. Ecol. Econ. 106, $112-123$.

Bialek, S., Shrader, J., 2019. Revealing Future Abatement Costs from Permit Banking Behavior. Resources for the Future. Available at. $h t t p s: / / w w w . r f f$. org/publications/working-papers/revealing-future-abatement-costs-permit -banking-behavior/.

Bird, L., Chapman, C., Logan, J., Sumner, J., Short, W., 2011. Evaluating renewable portfolio standards and carbon cap scenarios in the U.S. electric sector. Energy Policy 39 (5), 2573-2585.

Burkhardt, J., 2019. The impact of the renewable fuel standard on US oil refineries. Energy Policy 130, 429-437. https://doi.org/10.1016/j.enpol.2019.03.058.

Burkholder, D., 2015. A Preliminary Assessment of RIN Market Dynamics, RIN Prices, and their Effects. Report. Office of Transportation and Air Quality, US Environmental Protection Agency, Washington, DC.

California Air Resources Board (CARB)., 2020a. Low Carbon Fuel Standard Data Dashboard (Sacramento).

California Air Resources Board (CARB)., 2020b. Zero-Emission Vehicle Credit Balances (Sacramento).

Chen, X., Huang, H., Khanna, M., Önal, H., 2014. Alternative transportation fuel standards: welfare effects and climate benefits. J. Environ. Econ. Manag. 67 (3), 241-257. https://doi.org/10.1016/j.jeem.2013.09.006.

Collantes, G., Sperling, D., 2008. The origin of California's zero emission vehicle mandate. Transp. Res. A Policy Pract. 42 (10), 1302-1313.

Creutzig, F., Jochem, P., Edelenbosch, O.Y., Mattauch, L., van Vuuren, D.P., et al., 2015. Transport: a roadblock to climate change mitigation? Science 350 (6263), 911-912.

Davis, L.W., Knittel, C.R., 2019. Are fuel economy standards regressive? J. Assoc. Environ. Resour. Econ. 6 (S1), 37-63.

de Gorter, H., Just, D.R., 2010. The social costs and benefits of biofuels: the intersection of Environmental, energy and agricultural policy. Appl. Econ. Perspect. Policy 32 (1), 4-32.

DeCicco, J.M., 2012. Biofuels and carbon management. Clim. Chang. 111 (3), 627-640.

Dimanchev, E.G., Knittel, C.R., 2020. Trade-offs in Climate Policy: Combining LowCarbon Standards with Modest Carbon Pricing. MIT CEEPR Working Paper 2020020, November 2020.

Dimitropoulos, A., Oueslati, W., Sintek, C., 2018. The rebound effect in road transport: a meta-analysis of empirical studies. Energy Econ. 75 (C), 163-179.

Erutku, C., 2019. Carbon pricing pass-through: evidence from Ontario and Quebec's wholesale gasoline markets. Energy Policy 132, 106-112. https://doi.org/10.1016/ j.enpol.2019.05.026.

Farzad, T., Tyner, W.E., 2014. Welfare assessment of the renewable fuel standard: economic efficiency, rebound effect, and policy interactions in a general equilibrium framework. In: Pinto, A., Zilberman, D. (Eds.), Modeling, Dynamics, Optimization and Bioeconomics I, 73. Springer Proceedings in Mathematics Statistics.

Fischer, C., 2010. Imperfect competition, consumer behavior, and the provision of fuel efficiency in light- duty vehicles. In: Discussion Paper 10-60. Resources for the Future, Washington, DC.

Fischer, C., 2019. Market-Based Clean Performance Standards as Building Blocks for Carbon Pricing. Technical report. Hamilton Project.

Fischer, C., Preonas, L., 2012. Combining Policies for Renewable Energy: Is the Whole Less than the Sum of its Parts? SSRN Electronic Journal (March).

Forbes, 2017. Tesla's Lucrative ZEV Credits May Not Be Sustainable. September 12017.

GEA, 2012. Global Energy Assessment: Toward a Sustainable Future. Technical report. Cambridge University Press and the International Institute for Applied Systems Analysis, Cambridge, New York, and Laxenburg, Austria.

Gerard, D., Lave, L.B., 2005. Implementing technology-forcing policies: the 1970 clean Air act amendments and the introduction of advanced automotive emissions controls in the United States. Technol. Forecast. Soc. Chang. 72 (7), 761-778.

Gerarden, T., Newell, R.G., Stavins, R.N., Stowe, R., 2015. An Assessment of the EnergyEfficiency Gap and its Implications for Climate Change Policy (SSRN Electronic Journal).

Gillingham, K., Palmer, K., 2014. Bridging the energy efficiency gap: policy insights from economic theory and empirical evidence. Rev. Environ. Econ. Policy 8 (1), 18-38.

Gillingham, K., Stock, J.H., 2018. The cost of reducing greenhouse gas emissions. J. Econ. Perspect. 32 (4), 53-72. 
Goulder, L.H., Morgenstern, R.D., 2018. China's rate-based approach to reducing $\mathrm{CO}_{2}$ emissions: attractions, limitations, and alternatives. AEA Pap. Proc. 108, 458-462.

Goulder, L.H., Parry, I.W.H., Williams, R.C., 1999. The cost-effectiveness of alternative instruments for Environmental Protection in a second-best setting. J. Public Econ. 72, 329-360.

Greene, D.L., 1990. CAFE or Price?: an analysis of the effects of Federal Fuel Economy Regulations and gasoline Price on new Car MPG, 1978-89. Energy J. 11 (3), 37-57.

Greene, D.L., 1998. Why CAFE worked. Energy Policy 26 (8), 595-613.

Greene, D.L., 2012. Rebound 2007: analysis of U.S. light-duty vehicle travel statistics. Energy Policy 41, 14-28.

Greene, D.L., 2019. Implications of behavioral economics for the costs and benefits of fuel economy standards. Curr. Sustain. Renew. Energy Rep. 6 (4), 177-192.

Greene, D.L., Sims, C.B., Muratori, M., 2020. Two trillion gallons: fuel savings from fuel economy improvements to US light-duty vehicles, 1975-2018. Energy Policy 142, 111517.

Greenstone, M., Nath, I., 2019. Do renewable portfolio standards deliver? SSRN Electron. J. https://doi.org/10.2139/ssrn.3374942.

Heutel, G., 2015. Optimal policy instruments for externality-producing durable goods under present bias. J. Environ. Econ. Manag. 72, 54-70.

Heutel, G., 2020. In Defense of Alternatives to Pollution Pricing. Technical Report. Economists for Inclusive Prosperity.

Hill, J., Tajibaeva, L., Polasky, S., 2016. Climate consequences of low-carbon fuels: the United States renewable fuel standard. Energy Policy 97, 351-353.

Holland, S.P., Hughes, J.E., Knittel, C.R., 2009. Greenhouse gas reductions under low carbon fuel standards? Am. Econ. J. Econ. Pol. 1 (1), 106-146.

Huang, H., Khanna, M., Onal, H., Chen, X., 2013. Stacking low carbon policies on the renewable fuels standard: economic and greenhouse gas implications. Energy Policy $56,5-15$.

Hughes, J., Knittel, C.R., Sperling, D., 2008. Evidence of a shift in the Short-run Price elasticity of gasoline demand. Energy J. 29 (1).

Hymel, K.M., Small, K.A., 2015. The rebound effect for automobile travel: asymmetric response to Price changes and novel features of the 2000s. Energy Econ. 49, 93-103.

Hymel, K.M., Small, K.A., Dender, K.V., 2010. Induced demand and rebound effects in road transport. Transp. Res. B Methodol. 44 (10), 1220-1241.

Intergovernmental Panel on Climate Change (IPCC), 2014. Climate Change 2014: Mitigation of Climate Change: Working Group III Contribution to the IPCC Fifth Assessment Report.

Ito, K., Sallee, J.M., 2017. The economics of attribute-based regulation: theory and evidence from fuel economy standards. Rev. Econ. Stat. 100 (2), 319-336.

Jacobsen, M., 2013. Evaluating U.S. fuel economy standards in a model with producer and household heterogeneity. Am. Econ. J. Econ. Pol. 5 (2), 148-187.

Jenn, A., Azevedo, I.L., Michalek, J.J., 2019. Alternative-fuel-vehicle policy interactions increase U.S. greenhouse gas emissions. Transp. Res. A Policy Pract. 124, 396-407.

Johansson, R., Meyer, S., Whistance, J., Thompson, W., Debnath, D., 2020. Greenhouse gas emission reduction and cost from the United States biofuels mandate. Renew. Sust. Energ. Rev. 119, 109513. https://doi.org/10.1016/j.rser.2019.109513.

Kerr, S., Newell, R.G., Sep., 2003. 2003. Policy-induced technology adoption: evidence from the U.S. Lead phasedown. J. Ind. Econ. 51 (3), 317-343.

Klier, T., Linn, J., 2016. The effect of vehicle fuel economy standards on technology adoption. J. Public Econ. 133 (C), 41-63.

Knittel, C.R., Meiselman, B.S., Stock, J.H., 2017. The pass-through of RIN prices to wholesale and retail fuels under the renewable fuel standard. J. Assoc. Environ. Resour. Econ. 4 (4), 1081-1119. https://doi.org/10.1086/692071.

Lade, G.E., Bushnell, J., 2019. Fuel subsidy pass-through and market structure: evidence from the renewable fuel standard. J. Assoc. Environ. Resour. Econ. 6 (3), 563-592. https://doi.org/10.1086/702878.

Leard, B., McConnell, V., 2017. New markets for credit trading under U.S. automobile greenhouse gas and fuel economy standards. Rev. Environ. Econ. Policy 11 (2), 207-226.

Lee, J., Veloso, F.M., Hounshell, D.A., Rubin, E.S., 2010. Forcing technological change: a case of automobile emissions control technology development in the US. Technovation 30 (4), 249-264.

Lehmann, P., 2013. Supplementing an emissions tax by a feed-in tariff for renewable electricity to address learning spillovers. Energy Policy 61, 635-641.

Li, S., Linn, J., Muehlegger, E., 2014. Gasoline taxes and consumer behavior. Am. Econ. J. Econ. Pol. 6 (4), 302-342.

Lin, C.-Y.C., Prince, L., 2009. The optimal gas tax for California. Energy Policy 37 (12), 5173-5183.

Lin, C.-Y.C., Prince, L., 2013. Gasoline Price volatility and the elasticity of demand for gasoline. Energy Econ. 38, 111-117.

Liu, C., Greene, D.L., 2014. Vehicle manufacturer technology adoption and pricing strategies under fuel economy/emissions standards and Feebates. Energy J. 35 (3).

Mansur, E.T., Holland, S.P., Muller, N.Z., Yates, A.J., 2016. Are there Environmental benefits from driving electric vehicles? The importance of local factors. Am. Econ. Rev. 106 (12), 3700-3729.

Meckling, J., Sterner, T., Wagner, G., 2017. Policy sequencing toward Decarbonization. Nat. Energy 2 (12), 918-922.

Michalek, J.J., Papalambros, P.Y., Skerlos, S.J., 2005. A study of fuel efficiency and emission policy impact on optimal vehicle design decisions. J. Mech. Des. 126 (6), 1062-1070.

Morrow, W.R., Gallagher, K.S., Collantes, G., Lee, H., 2010. Analysis of policies to reduce oil consumption and greenhouse-gas emissions from the US transportation sector. Energy Policy 38 (3), 1305-1320.
Münzel, C., Plötz, P., Sprei, F., Gnann, T., 2019. How large is the effect of financial incentives on electric vehicle sales? A global review and European analysis. Energy Econ. 84, 104493.

National Highway Traffic Safety Administration (NHTSA), 2020. CAFE Public Information Center.

National Research Council (NRC), 2011. Renewable Fuel Standard: Potential Economic And Environmental Effects of U.S. Biofuel Policy. Technical report. National Research Council Production. Committee on Economic and Environmental Impacts of Increasing Biofuels (U.S.).

Nelson, T., Reid, C., McNeill, J., 2015. Energy-only markets and renewable energy targets: complementary policy or policy collision? Econ. Analys. Policy 46, 25-42.

Nentjes, A., Woerdman, E., 2012. Tradable permits versus tradable credits: a survey and analysis. Int. Rev. Environ. Resour. Econ. 6 (1), 1-78.

Nentjes, A., de Vries, F.P., Wiersma, D., 2007. Technology-forcing through Environmental regulation. Eur. J. Polit. Econ. 23 (4), 903-916.

Ogden, J.M., 1999. Prospects for building a hydrogen energy infrastructure. Annu. Rev. Energy Environ. 24 (1), 227-279.

Pahle, M., Burtraw, D., Flachsland, C., Kelsey, N., Biber, E., et al., 2018. Sequencing to ratchet up climate policy stringency. Nat. Clim. Chang. 8 (10), 861-867.

Peterson, S.B., Michalek, J.J., 2013. Cost-effectiveness of plug-in hybrid electric vehicle battery capacity and charging infrastructure Investment for Reducing US gasoline consumption. Energy Policy 52, 429-438.

Pezzey, J.C.V., Jotzo, F., 2013. Carbon tax needs thresholds to reach its full potential. Nat. Clim. Chang. 3 (12), 008-011.

Pollitt, H., Neuhoff, K., Lin, X., 2020. The impact of implementing a consumption charge on carbon-intensive materials in Europe. Clim. Pol. 20, S74-S89.

Rajagopal, D., Hochman, G., Zilberman, D., 2011. Indirect fuel use change (IFUC) and the lifecycle Environmental impact of biofuel policies. Energy Policy 39 (1), 228-233.

Rosenbloom, D., Markard, J., Geels, F.W., Fuenfschilling, L., 2020. Opinion: why carbon pricing is not sufficient to mitigate climate change - and how "sustainability transition policy" can help. Proc. Natl. Acad. Sci. 117 (16), 8664-8668.

Rubin, J., Leiby, P.N., 2013. Tradable credits system design and cost Savings for a National low Carbon Fuel Standard for road transport. Energy Policy 56, 16-28.

Rubin, J., Leiby, P.N., Greene, D.L., 2009. Tradable fuel economy credits: competition and oligopoly. J. Environ. Econ. Manag. 58 (3), 315-328.

Sallee, J.M., 2011. The surprising incidence of tax credits for the Toyota Prius. Am. Econ. J. Econ. Pol. 3 (2), 189-219.

Schnepf, R., Yacobucci, B.D., 2013. Renewable Fuel Standard (RFS): Overview and Issues. Technical Report. Congressional Research Service, Washington, DC.

Sen, B., Noori, N., Tatari, O., 2017. Will corporate average fuel economy (CAFE) standard help? Modeling CAFE's impact on market share of electric vehicles. Energy Policy 109, 279-287.

Small, K.A., Van Dender, K., 2007. Fuel efficiency and motor vehicle travel: the declining rebound effect. Energy J. 28 (1).

Sperling, D., Nichols, M., 2012. California's pioneering transportation strategy. Issues Sci. Technol. 28 (2), 59-66.

Sperling, D., Yeh, S., 2009. Low Carbon Fuel Standards. Issues in Science and Technology, Winter, pp. 57-66.

Sterner, T., 2007. Fuel taxes: an important instrument for climate policy. Energy Policy 35 (6), 3194-3202.

Tilman, D., Socolow, R., Foley, J.A., Hill, J., Larson, E., et al., 2009. Beneficial biofuels: the food, energy, and environment Trilemma. Science 325 (5938), 270-271.

Tracy, K., 2010. Rocky Mountain farmers union v. Goldstene: low carbon fuel standards, lifecycle greenhouse gases, and California's continued struggle to Lead the way. Tulane Environ. Law J. 24, 173.

Tsao, C.-C., Campbell, J.E., Chen, Y., 2011. When renewable portfolio standards meet cap-and-trade regulations in the electricity sector: market interactions, profits implications, and policy redundancy. Energy Policy 39 (7), 3966-3974.

US Environmental Protection Agency (EPA), 2019. Renewable Identification Number (RIN) Data for Renewable Fuel Standard Program. Washington, DC.

US Environmental Protection Agency (EPA), 2020. The 2019 Automotive Trends Report. Technical Report epa-420-r-20-006. Washington, DC, March.

Wesseling, J.H., Farla, J.C.M., Sperling, D., Hekkert, M.P., 2014. Car manufacturers changing political strategies on the ZEV mandate. Transp. Res. Part D: Transp. Environ. 33, 196-209.

Wesseling, J.H., Farla, J.C.M., Hekkert, M.P., 2015. Exploring car manufacturers' responses to technology-forcing regulation: the case of California's ZEV mandate. Environ. Innov. Soc. Trans. 16, 87-105.

Witcover, J., 2018. Status Review: LCFS, 2011-2018. Technical Report Ucd-its-Rr-18-25. Institute of Transportation Studies, University of California, Davis, September.

Yeh, S., Sperling, D., 2010. Low carbon fuel standards: implementation scenarios and challenges. Energy Policy 38 (11).

Yeh, S., Lutsey, N., Parker, N., 2009. Assessment of technologies to meet a low carbon fuel standard. Environ. Sci. Technol. 43 (18).

Yeh, S., Witcover, J., Lade, G.E., Sperling, D., 2016. A review of low carbon fuel policies: principles, program status and future directions. Energy Policy 97, 220-234.

Yeh, S., Mishra, G.S., Fulton, L., Kyle, P., McCollum, D.L., et al., 2017. Detailed assessment of global transport-energy Models' structures and projections. Transp. Res. Part D: Transp. Environ. 55, 294-309. 